\title{
1,2,4- and 1,3,4-Oxadiazoles as Scaffolds in the Development of Antiparasitic Agents
}

\author{
Paulo Pitasse-Santos, ${ }^{a}$ Vitor Sueth-Santiago ${ }^{b}$ and Marco E. F. Lima ${ }^{*, a}$ \\ ${ }^{a}$ Departamento de Química, Universidade Federal Rural do Rio de Janeiro, \\ BR-465, km 7, 23897-000 Seropédica-RJ, Brazil \\ ${ }^{b}$ Instituto Federal de Educação, Ciência e Tecnologia do Rio de Janeiro, \\ Rua José Augusto Pereira dos Santos, s/n, 24425-004 São Gonçalo-RJ, Brazil
}

\begin{abstract}
In this review, we present the potential use of the heterocyclic oxadiazole rings in the design and synthesis of new drugs to treat parasitic infections. We intend to compare herein all the four isomeric forms of oxadiazole rings as well as discuss the differences and similarities between them. In addition, we discuss aspects on their reactivity that justify the great importance of both 1,2,4- and 1,3,4-oxadiazoles isomers when compared with their other two isomers. Although some oxadiazole isomers satisfy Hückel's rule, there are differences concerning their aromaticity, which have a great impact on the possible interactions of the oxadiazole ring with biological receptors. The set of works selected from the literature and discussed herein points out the oxadiazole core as an important and versatile scaffold in the development of new chemical entities potentially useful as antiparasitic drugs.
\end{abstract}

Keywords: drug design, bioisosterism, heterocyclic drugs, anti-infective drugs

\section{Introduction}

\subsection{Nitrogen heterocycles and drug discovery}

Nitrogen heterocycles play an important role in the drug discovery scenario. ${ }^{1}$ The nitrogenated cores commonly occur as fragments in the structure of most drugs with varied ring sizes; aromatic and nonaromatic rings; fused and bicyclic rings. Nitrogen heterocyclic drugs are present in all therapeutic areas including cardiovascular and metabolic illnesses, central nervous system (CNS) disorders, antiinflammatory, antineoplastic, anti-infective drugs, among others. In the remarkable review published by Njardarson's group, ${ }^{2}$ from the University of Arizona, the authors indicate that $59 \%$ of unique small-molecule drugs approved by the FDA (Food and Drug Administration, USA) contain a nitrogen heterocycle. Figure 1 shows the 881 FDAapproved drugs containing a nitrogen heterocycle presented by ring size among other structural profiles. $^{2}$

Figure 2 shows four examples of bestseller drugs containing nitrogen heterocyclic systems in their structures. Atorvastatin (1, Pfizer) is a statin that acts to inhibit HMG-CoA reductase, an enzyme that plays a key role

*e-mail: marco@ufrrj.br, marcoedilson@gmail.com in the production of cholesterol. Sildenafil (2, Pfizer) is a PDE5 inhibitor used clinically in the treatment of erectile dysfunction. Imatinib (3, Novartis) is a 2-phenylaminopyrimidine derivative which functions as a specific inhibitor of several tyrosine kinase enzymes. Imatinib is a drug used to treat chronic myelogenous leukemia and other types of cancers. Losartan (4, Merck \& Co) is an antagonist of angiotensin II type 1 receptor $\left(\mathrm{AT}_{1}\right)$, indicated for the treatment of hypertension (Figure 2$){ }^{3}$

Figure 3 shows the structures of five heterocyclic anti-infective agents. Ketoconazole (5) is an important imidazolic antifungal that acts inhibiting the enzyme responsible for fungal ergosterol biosynthesis, $14 \alpha$-demethylase. ${ }^{4}$ Metronidazole (6) and benznidazole (7) are two antiprotozoal drugs acting through the generation of intracellular radical species which can damage both parasites' DNA and other cellular machinery. ${ }^{5}$ The antibacterial fluoroquinolone ciprofloxacin (8) acts through the damage of bacterial DNA. ${ }^{6}$ Raltegravir (9) is an HIV-1 integrase inhibitor, useful for the treatment of HIV infections. ${ }^{7}$

\section{The Oxadiazole Core}

Oxadiazoles are heterocyclic compounds composed 


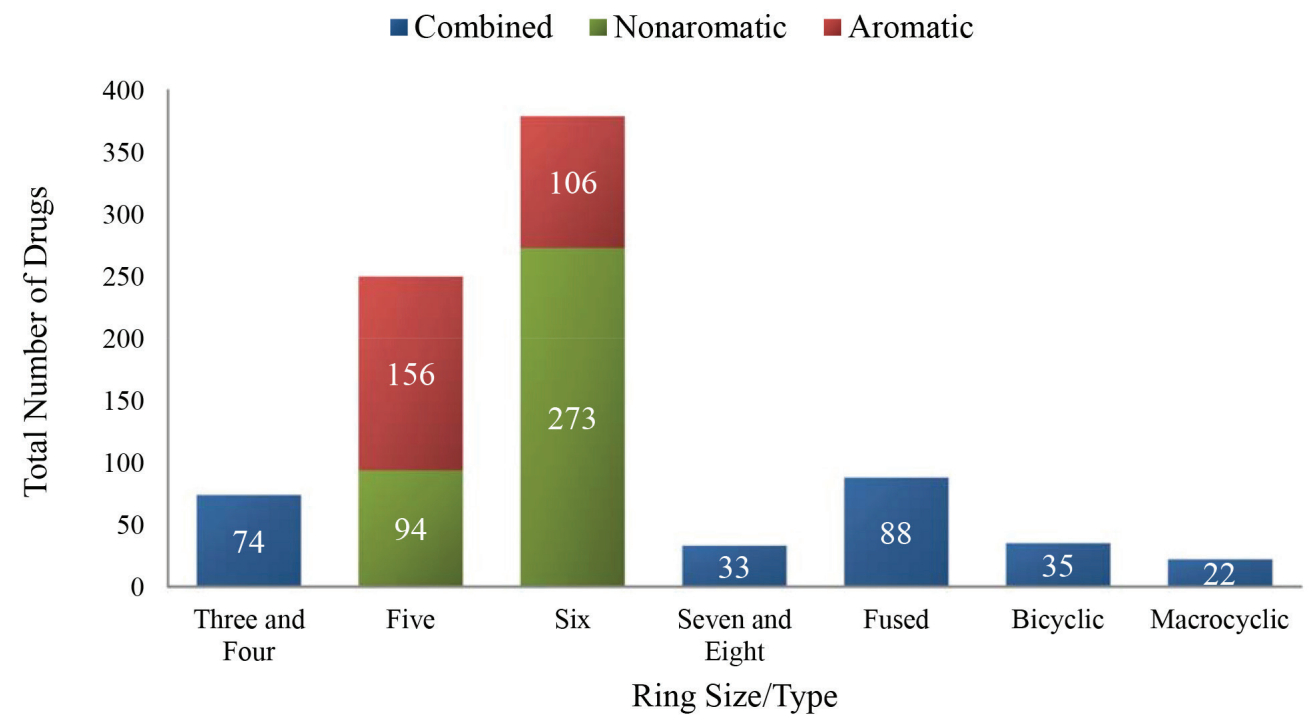

Figure 1. Nitrogen containing heterocycles and their relative distribution among the FDA approved drugs (adapted from reference 2).

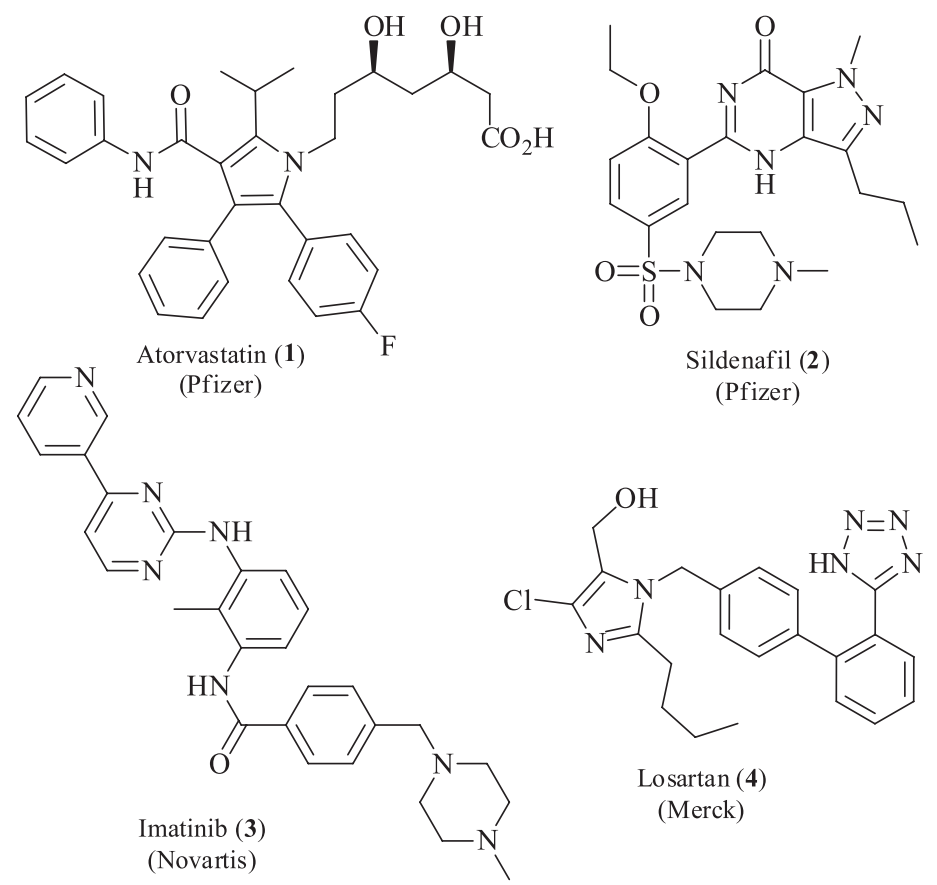

Figure 2. Structures of some bestselling drugs containing nitrogen heterocyclic rings.

by two atoms of carbon, two atoms of nitrogen and one atom of oxygen. They were firstly discovered in 1884 by Tiemann and Krüger, ${ }^{8}$ then named furo[ab]diazoles. Oxadiazoles can be isosterically compared with furan, ${ }^{9}$ but the replacement of two methine groups $(-\mathrm{CH}=)$ by two $\mathrm{sp}^{2}$ nitrogen $(-\mathrm{N}=)$ reduces their aromaticity so that some of their isomers are electronically comparable to conjugated diene systems. Oxadiazoles can be found in four different isomeric structures (Figure 4). ${ }^{10}$

It is possible to find molecules bearing oxadiazole moieties with application in several areas, as luminescent materials, ${ }^{11}$ electron-transport materials, ${ }^{12}$ polymers, ${ }^{13}$ herbicides, ${ }^{14}$ and corrosion inhibitors, ${ }^{15}$ for example. This review will focus on molecules with importance to medicinal chemistry, more specifically to the development of new chemical entities with antiparasitic properties. The stability of the oxadiazole rings in aqueous medium is one of the most important characteristics that justify the interest in the development of bioactive molecules containing this motif. 1,2,4-Oxadiazole rings, for example, are stable even in the presence of concentrated sulfuric acid. ${ }^{8}$ Another relevant aspect of oxadiazoles is their capability of acting as a hydrogen bond acceptor, due to the nonligand electron pairs from the heteroatoms present 


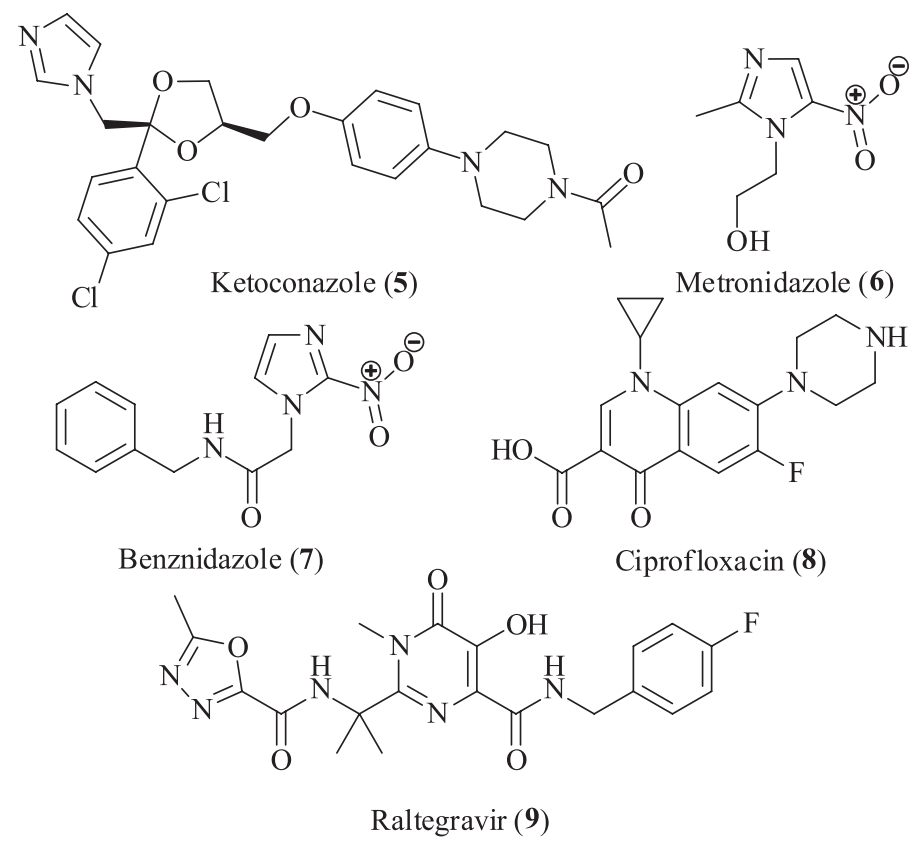

Figure 3. Structures of some anti-infective heterocyclic drugs.<smiles>[R]c1nnoc1[14CH3]</smiles><smiles></smiles>

Figure 4. The four oxadiazole isomers.

in their structures. ${ }^{16}$ In drug discovery and development, oxadiazole rings are commonly employed as bioisosteric replacement for carbonyl-containing groups such as esters, amides, carbamates and hydroxamic esters. Such groups are usually unstable in biological media, which poses as an obstacle for their use in the structure of drug candidates. ${ }^{17}$ At the same time, their spatial geometry is similar to the oxadiazole bioisosters, so the new compounds shall bind similarly at the same bioactive sites. ${ }^{18}$

For a long time, oxadiazolic rings could only be obtained via synthetic routes. However, in 2011, two naturally occurring 1,2,4-oxadiazoles were found: phidianidines A (10a) and B (10b), whose structures are shown in Figure 5. Such molecules were isolated from the aeolid opisthobranch Phidiana militaris, ${ }^{19}$ a shell-less marine mollusk that inhabits Southern India. ${ }^{20}$ The natural phidianidines displayed a potent and selective cytotoxic profile against tumor and nontumor cell lines (C6, HeLa, CaCo-2, 3T3-L1 and H9c2). In addition, they exhibited selective binding properties with CNS sites, such as the $\mu$-opioid receptor and the dopamine transporter. These features represent an interesting starting point for chemical optimization based on phidianidine's structure targeting cancer, pain treatment and some CNS diseases. ${ }^{21}$

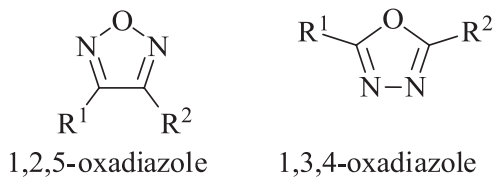

1,2,5-oxadiazole 1,3,4-oxadiazole

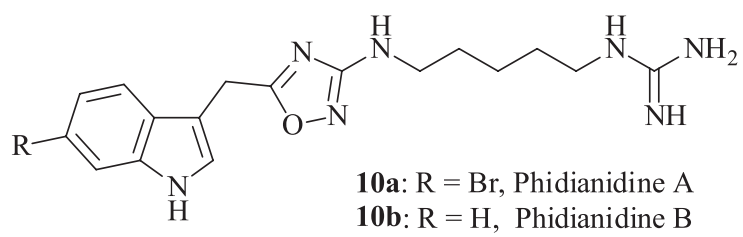

Figure 5. Molecular structure of the naturally occurring 1,2,4-oxadiazoles phidianidines A and B, isolated from the aeolid opisthobranch Phidiana militaris.

Bioactive molecules containing the oxadiazole ring have increasingly been discovered and studied over the last few years (Figure 6) ${ }^{22}$ It is possible to find the oxadiazole group in various molecules with reported activity as antitumor, ${ }^{23}$ antioxidant,${ }^{24}$ antibacterial,,${ }^{25}$ antiviral,${ }^{26}$ antiinflammatory, ${ }^{27}$ insecticidal ${ }^{28}$ and antiparasitic ${ }^{29}$ agents, for example.

One can observe that the 1,2,4- and 1,3,4- isomers of oxadiazolic rings are significantly more common in medicinal chemistry than both their 1,2,3- and 1,2,5analogues. 1,2,3-Oxadiazoles are commonly observed in the diazoketone tautomeric form, due to its instability in the cyclic form. Studies have shown that 3-oxides of 1,2,3-oxadiazoles are more stable structures. However, the complicated synthetic route for their preparation 


\section{घ 1,2,3-oxadiazoles $\square 1,2,4$-oxadiazoles $\square$ 1,2,5-oxadiazoles $\square 1,3,4$-oxadiazoles}

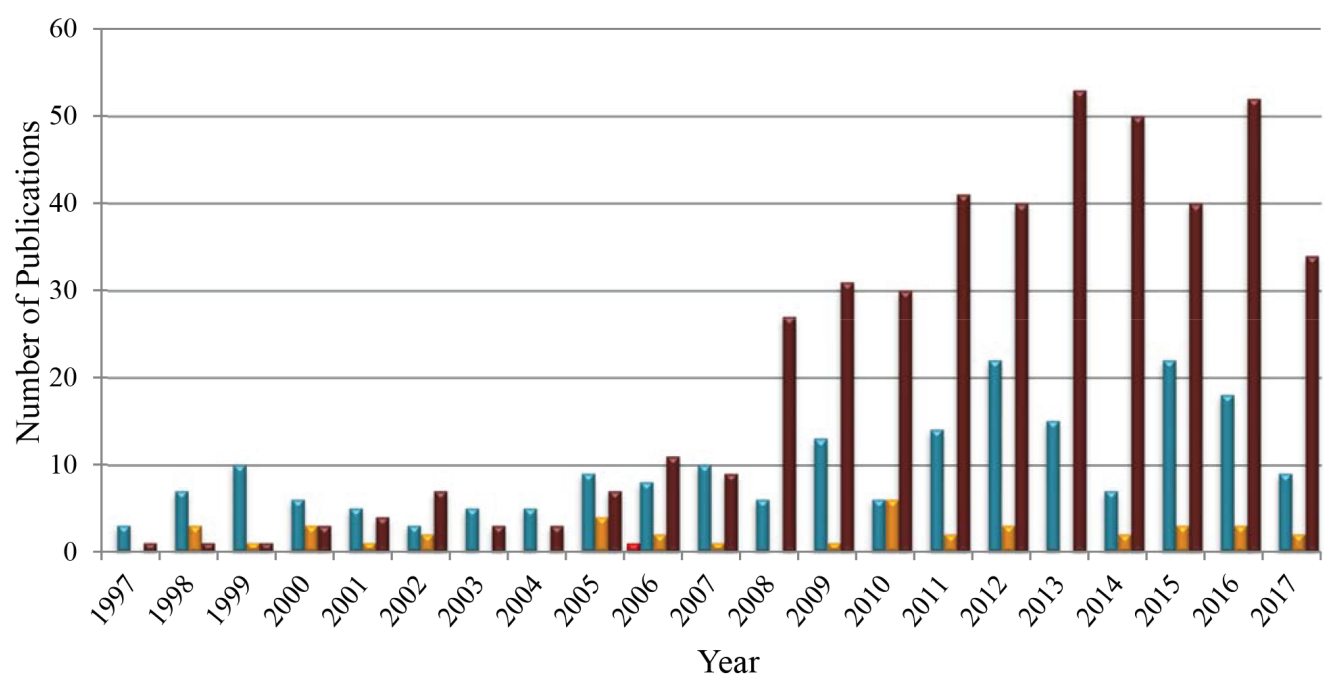

Figure 6. Annual publications related to oxadiazoles on medicinal chemistry over the period from 1997 to $2017 .^{22}$

still restricts the exploration of this isomeric form. ${ }^{30}$ 1,2,5-Oxadiazoles are more stable structures and more explored in medicinal chemistry research, including as antiparasitic agents. ${ }^{31}$ In spite of that, this isomeric form orients side chains to different positions compared with 1,2,4- and 1,3,4-oxadiazole counterparts, which display closer chain arrangement comparing to most natural ligands. ${ }^{18}$ Recently, Andricopulo and co-workers ${ }^{32}$ reported the development of a 2D-QSAR- (quantitative structure-activity relationship) and 3D-QSAR-based pharmacophore for cruzain using several differently substituted oxadiazoles as molecular probes. This abundant $T$. cruzi cysteine protease is a validated biochemical target to the development of antichagasic chemotherapy. The wider application of 1,2,4- and 1,3,4-oxadiazoles on medicinal chemistry is also observed regarding research on antiparasitic agents. Therefore, this review will focus on the physicochemical and biological properties, synthetic methods and antiparasitic applications of such isomers.

\section{Differences between 1,2,4- and 1,3,4-Oxadiazoles}

Although both 1,2,4- and 1,3,4-oxadiazoles satisfy Hückel rule (a cyclic and planar system containing $4 n+2$ electrons), there are differences concerning their aromaticity. The idea that 1,2,4-oxadiazoles do not behave as aromatic compounds was experimentally confirmed in 1964 by Moussebois and Oth, ${ }^{33}$ when the authors compared UV spectra of several aryl-substituted oxadiazole compounds. The chemical structures and maximum absorption wavelength values $\left(\boldsymbol{\lambda}_{\max }\right)$ of 3-phenyl1,2,4-oxadiazole (11), 5-phenyl-1,2,4-oxadiazole (12) and 3,5-diphenyl-1,2,4-oxadiazole (13) derivatives are shown in Figure 7. If the 1,2,4-oxadiazolic ring had considerable aromaticity, the presence of the two phenyl rings would cause a bathochromic effect on the $\lambda_{\max }$ of these substances. This would decrease the amount of energy required for the $\pi \rightarrow \pi^{*}$ transition due to an increase in the conjugation. However, Moussebois and $\mathrm{Oth}^{33}$ found the $\lambda_{\max }$ values of $238 \mathrm{~nm}$ for $\mathbf{1 1}$ (3-phenyl substituted), $250 \mathrm{~nm}$ for $\mathbf{1 2}$ (5-phenyl substituted) and curiously an intermediate value of $245 \mathrm{~nm}$ for derivative $\mathbf{1 3}$ (3,5-diphenyl substituted). These results indicate that the heterocyclic ring does not have significant aromaticity and is better described as a conjugated diene. 1,3,4-Oxadiazole derivatives, for their part, behave differently. It was observed that the presence of two phenyl rings considerably increases the observed $\lambda_{\max }$ value. For example, 2-phenyl-1,3,4-oxadiazole (14) has a $\lambda_{\max }=245 \mathrm{~nm},{ }^{34}$ whereas the 2,5-diphenyl-1,3,4-oxadiazole (15) analogue has a $\lambda_{\max }=276 \mathrm{~nm}$ (Figure 7). ${ }^{35}$ The analysis of UV spectra information allows us to infer that 1,3,4-oxadiazoles have greater aromaticity, presumably because of their symmetry.

These physicochemical properties reflect in the reactivity of each heterocycle. For example, 1,2,4-oxadiazoles can react with strong nucleophiles such as $n$-butyllithium in THF (tetrahydrofuran) at $-78^{\circ} \mathrm{C}$, via a nucleophilic addition, to form the derivatives depicted below (Figure 8). ${ }^{36}$ However, 1,3,4-oxadiazoles do not react under the same reaction condition due to the fact they are much less electrophilic. It is certainly linked to the aromaticity of the 1,3,4-oxadiazolic core, which favors substitution in place of addition reactions. 
<smiles>c1ccc(-c2ncon2)cc1</smiles>

11<smiles>c1ccc(-c2noc(-c3ccccc3)n2)cc1</smiles>

13<smiles>c1ccc(-c2nnco2)cc1</smiles>

12<smiles>c1ccc(-c2nnc(-c3ccccc3)o2)cc1</smiles>

\begin{tabular}{lc}
\hline Compound & $\lambda_{\max } / \mathrm{nm}$ \\
\hline $\mathbf{1 1}$ & 238 \\
$\mathbf{1 2}$ & 250 \\
$\mathbf{1 3}$ & 245 \\
$\mathbf{1 4}$ & 245 \\
$\mathbf{1 5}$ & 276 \\
\hline
\end{tabular}

Figure 7. Chemical structures and maximum absorption wavelength values $\left(\lambda_{\max }\right)$ for oxadiazoles 11-15. UV data suggest that 1,2,4-oxadiazoles behave as conjugated dienes whereas 1,3,4-oxadiazoles have higher aromatic character.<smiles>CCCCC1([123I])NC([Al])=NO1</smiles>

nBuLi

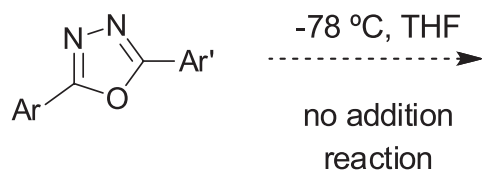

Figure 8. Addition reaction of $n$-butyllithium to 3,5-diaryl1,2,4-oxadiazoles.

3.1. Structural profile of 1,3,4- and 1,2,4-oxadiazoles driving their intermolecular interactions with biomacromolecules

The 1,3,4-oxadiazole core's properties are similar to an aromatic heterocycle. Being so, it has typical interactions of aromatic systems, such as $\pi-\pi$ stacking with hydrophobic amino acids such as tyrosine, phenylalanine and tryptophan. Dhumal et al. ${ }^{37}$ synthesized a series of 1,3,4-oxadiazoles aiming to inhibit the mycobacterial enoyl reductase (InhA) of Mycobacterium tuberculosis. Docking studies carried out by Dhumal et al. ${ }^{37}$ on InhA showed that the oxadiazole core of 16 interacts with Phe149 and Tyr158 through a $\pi-\pi$ stacking, as shown in Figure 9. This kind of interaction also happens in other 1,3,4-oxadiazoles designed by the authors, ${ }^{37}$ with relevant changes only at the level of the other structure decorations present, like a pyridine ring.

Another possible interaction involving 1,3,4-oxadiazoles and proteins is the cation- $\pi$ interaction. This type of noncovalent interaction is rather uncommon and quite different from the complexes of transition metals and $\pi$-systems because of the d orbitals present in the metal. The interaction is based on the effects caused by the proximity of a monopole (the cation) and a quadrupole

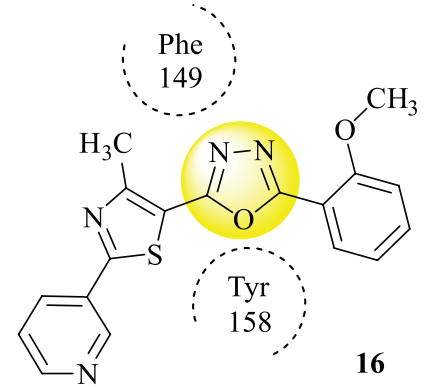

Figure 9. Schematic model of the $\pi-\pi$ stacking interaction between the oxadiazole derivative $\mathbf{1 6}$ and the aromatic aminoacids of the binding site of Mycobacterium tuberculosis mycobacterial enoyl reductase.

(the electron-rich $\pi$-system). ${ }^{38}$ Taha et al. ${ }^{39}$ synthesized a series of $\alpha$-glucosidase inhibitors with a 5-aryl2-(6'-nitrobenzofuran-2'-yl)-1,3,4-oxadiazole scaffold. Compound $\mathbf{1 7}$ was the second most active (the first one was the reference drug, acarbose). Docking studies show that the 1,3,4-oxadiazole moiety interacted with residue His 279 by a cation- $\pi$ interaction, as shown in Figure $10 .{ }^{39}$

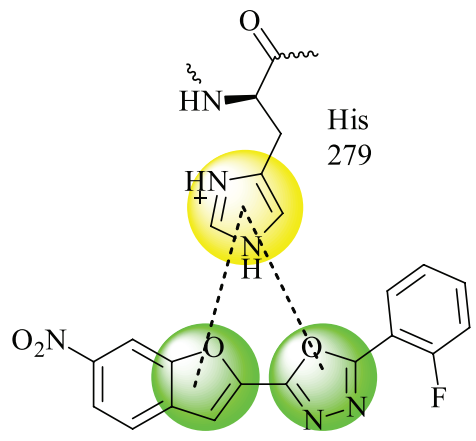

17

Figure 10. Schematic cation- $\pi$ interaction between the 1,3,4-oxadiazole moiety present in derivative $\mathbf{1 7}$ and His279 of the Saccharomyces cerevisiae $\alpha$-glucosidase.

Considering the aromaticity of the 1,3,4-oxadiazole core as a $6 \pi$ electron system, the two nitrogen atoms have each one electron pair fully available to receive a hydrogen bond. These interactions are observed in the binding site 
<smiles>Cc1nnc(C(=O)NC(C)(C)c2nc(C(=O)NCc3ccc(F)cc3)c(O)c(=O)n2C)o1</smiles>

(a)

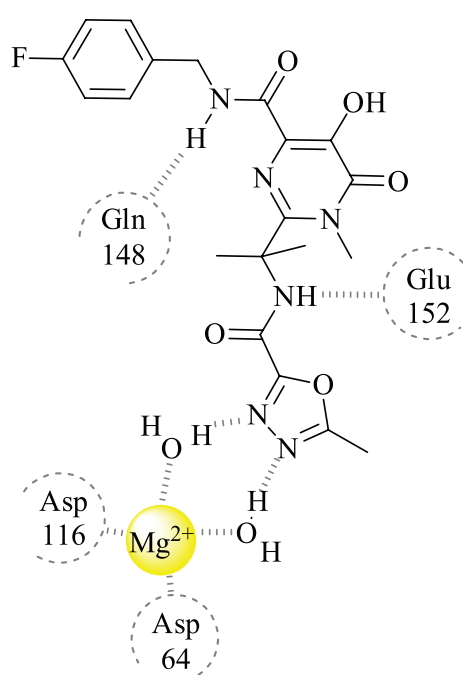

(b)

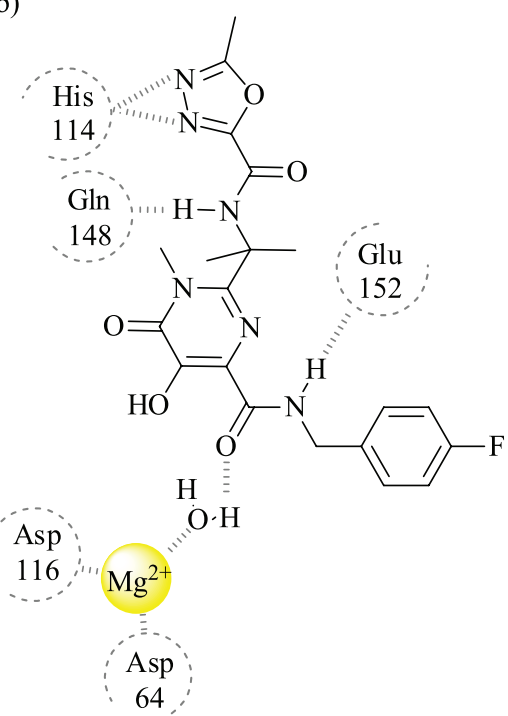

Figure 11. 2D representation of the best binding poses of raltegravir (9, up) in HIV-1 integrase: (a) interaction between the 1,3,4-oxadiazole moiety and the cation $\mathrm{Mg}^{2+}$ linked by two water molecules in a hydrogen bond; (b) oxadiazole core interacting with His 114 via a cation- $\pi$ interaction.

of raltegravir (9) in the HIV-1 integrase. The nitrogens are linked to the cation $\mathrm{Mg}^{2+}$ by two water molecules, as shown in Figure 11a. Curiously, in another possible binding pose, the oxadiazole moiety can also interact with histidine residue His 114 by a cation- $\pi$ interaction as presented before (Figure 11b). ${ }^{40}$

In a different manner, the 1,2,4-oxadiazole motif present on derivative 18 forms a hydrogen bond with Thr206 of the binding pocket of the $\mathrm{GABA}_{\mathrm{A}}$ receptor, even being close to Tyr209. This might be explained by the less aromatic profile of this heterocycle, as seen in Figure 12.41

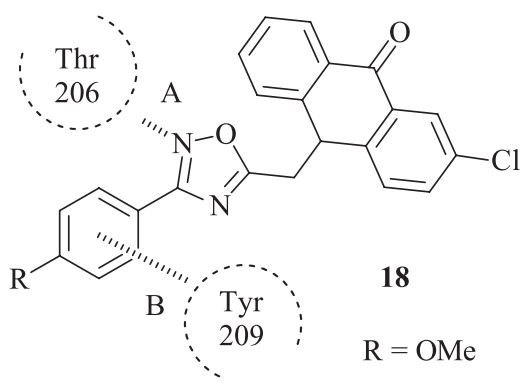

Figure 12. Schematic representation of the $\mathbf{1 8}$ derivative forming a hydrogen bond between the 1,2,4-oxadiazole ring and threonine (A) and a $\pi-\pi$ stacking with tyrosine via the methoxyphenyl ring (B).

Kamal et $a l .{ }^{42}$ reported a series of 1,2,4-oxadiazolic derivatives, such as 19a-b, which tend to form hydrophobic interactions between the heterocycle and $\alpha$-Thr179 apart from $\pi$ - $\pi$ stacking with $\beta$-Asn 258 on the colchicine binding site of bovine tubulin (Figure 13).<smiles>[R]c1ccc2[nH]c(-c3ccc(-c4noc(C(I)(CI)CCI)n4)cc3)nc2c1</smiles>

Figure 13. Hydrophobic interaction between Thr179 on the colchicine binding site of bovine tubulin and 1,2,4-oxadiazole derivatives 19a-b.

\section{Synthetic Methodologies for Obtaining 1,2,4- and 1,3,4-Oxadiazolic Rings}

\subsection{Synthesis of 1,2,4-oxadiazoles}

The classic synthetic routes for 1,2,4-oxadiazoles rely in the use of nitriles as precursors, as shown in Scheme 1: (a) one approach is based on the 1,3-dipolar cycloaddition of nitriles to nitrile $N$-oxides; (b) the second approach is through obtaining an amidoxime intermediate from a nitrile followed by $O$-acylation of the amidoxime and cyclization of the $O$-acylamidoxime as the final step. ${ }^{9}$ 
(a)

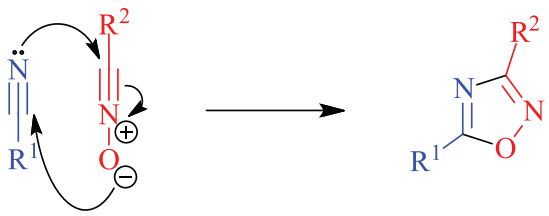

(b)

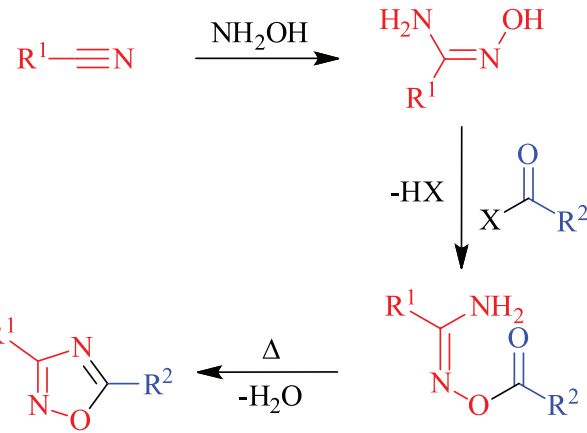

Scheme 1. Classic synthetic routes for obtaining 1,2,4-oxadiazoles: (a) nitrile oxide route; (b) amidoxime route.

The formation of the 1,2,4-oxadiazolic ring via amidoxime route needs an acylating agent, which carries the substituent group that will be positioned at $\mathrm{C}_{5}$. Mohammadi-Khanaposhtani et al..$^{41}$ reacted differently substituted benzamidoximes (20) with 2-chloro acetyl chloride (21) as acylant agent. Because of their high reactivity, acyl chlorides enable reactions of $O$-acylation at room temperature, yielding the acylamidoximes (22). The reaction to form 1,2,4-oxadiazole intermediates (23) was then carried out in toluene under reflux, followed by an $S_{\mathrm{N}} 2$ reaction with differently substituted acridones (24), yielding compounds $\mathbf{1 8}$ with anticonvulsant profiles (Scheme 2). ${ }^{41}$

Outirite $\mathrm{et} \mathrm{al} .{ }^{43}$ presented a faster and easier methodology to prepare 1,2,4-oxadiazoles as part of a program focused on antibacterial agents and corrosion inhibitors. They used aromatic nitriles (25) in the presence of hydroxylamine hydrochloride and sodium carbonate in ethylene glycol/ water $3: 1$ as solvent. The reaction was carried out under microwave irradiation until reflux for $2 \mathrm{~h}$ in a one-pot reaction (Scheme 3). Yields ranging from 71 to $92 \%$, simpler experimental procedure, lower reaction times and, consequently, lower energy consumption than previous methods are interesting features of this experimental procedure. On the other hand, it only allows the synthesis of symmetrically substituted 1,2,4-oxadiazoles (26). ${ }^{43}$

It is also possible to find protocols employing ultrasound irradiation to synthesize 1,2,4-oxadiazoles (29), as reported by Bretanha et al. ${ }^{44}$ Short reaction times $(15 \mathrm{~min})$ and high yields (84-98\%) were reported for the reaction between trichloroacetoamidoxime (27) and the properly substituted benzoyl chlorides (28) in ethyl acetate as solvent (Scheme 4). ${ }^{44}$

In a different approach, Yoshimura et al ${ }^{45}$ reacted nitrile oxides (34) and nitriles (31) to obtain 1,2,4-oxadiazoles (32). Hydroxy(aryl)iodonium (IBA-OTf, 33) was employed allowing the formation in situ of nitrile oxides (34) from the respective nitriles (31). IBA-OTf (33) can be generated in situ by addition of 2-iodo-benzoic acid (35), trifluoromethanesulfonic acid ( $\mathrm{TfOH})$ and<smiles>[R]c1ccc(/C(N)=N/O)cc1</smiles>

20<smiles>[R]c1ccc(-c2noc(Cn3c4ccccc4c(=O)c4cc([R])ccc43)n2)cc1</smiles>

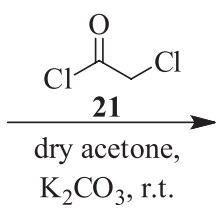<smiles>[R]c1ccc(/C(N)=N/OC(=O)CCl)cc1</smiles>

22<smiles>[R]c1ccc(-c2nc(CCl)no2)cc1</smiles>

Scheme 2. Preparation of 1,2,4-oxadiazoles (18) with anticonculsant profile.

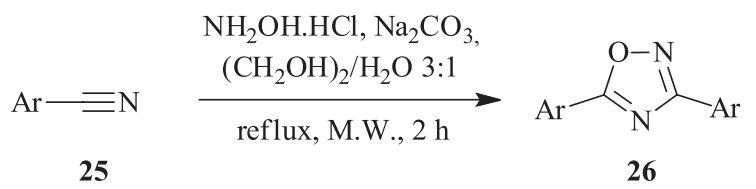

Scheme 3. Synthetic methodology for obtaining symmetrically substituted 1,2,4-oxadiazoles (26) as potential antibacterial agents and corrosion inhibitors. 
<smiles>N/C(=N\O)C(Cl)(Cl)Cl</smiles>

27<smiles>O=C(Cl)c1ccccc1</smiles>

28<smiles>[R][X]1=C=CC=C(c2nc(C(Cl)(Cl)Cl)no2)C=C1</smiles>

29

Scheme 4. 1,2,4-Oxadiazoles (29) synthesized under ultrasound irradiation.

meta-chloroperbenzoic acid ( $m$-CPBA) as oxidant. The proposed mechanism for the one-pot reaction is shown in Scheme $5 .{ }^{45}$

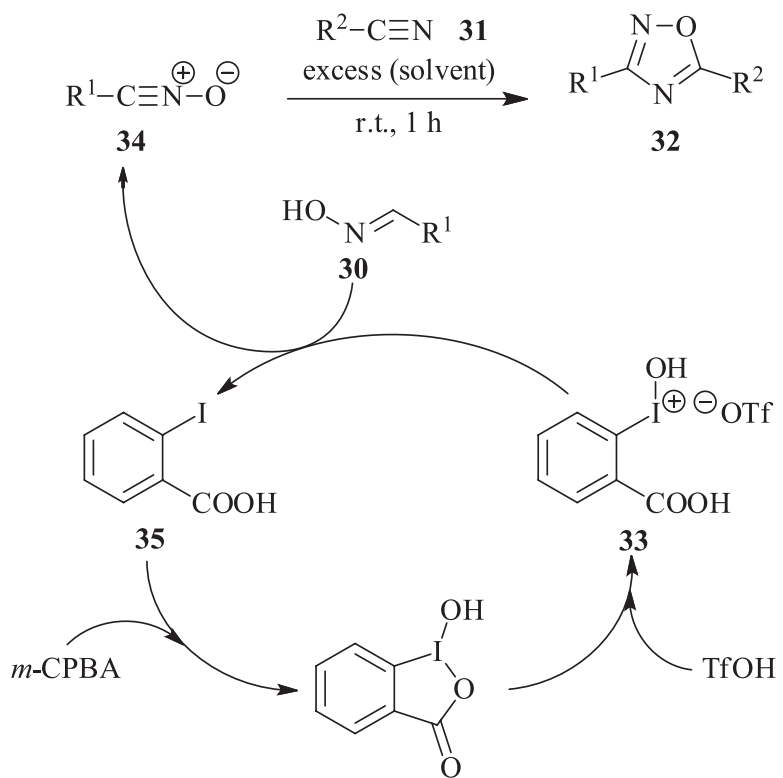

Scheme 5. Reaction mechanism for the formation of 1,2,4-oxadiazoles (32) in the presence of IBA-OTf (33).

Some recent protocols have been described for the formation of $O$-acylamidoxime intermediates using coupling reagents. In a recently published work, Karad et al. ${ }^{46}$ described the synthesis of 1,2,4-oxadiazoles as antimicrobial and antifungal agents. The properly substituted amidoximes (36) were obtained from the respective 2-morpholinoquinoline-3-carbonitriles (37). $O$-Acylation and cyclization steps were conducted in a one-pot reaction with the benzoic acids (38) in the presence of coupling reagent ethyl-( $N^{\prime}, N^{\prime}$-dimethylamino)propyl-carbodiimide hydrochloride (EDC.HCl). Next, oxadiazoles (39) were obtained through reflux of the acylated intermediate in ethanol in the presence of sodium acetate for $3 \mathrm{~h}$ (Scheme 6). ${ }^{46}$

Cao et al..$^{47}$ used coupling reagent 1 -[bis(dimethylamino) methylene]-1H-1,2,3-triazolo[4,5-b]pyridinium-3-oxidhexafluoro-phosphate (HATU) to obtain $O$-acylamidoxime intermediates. To do so, they first reacted differently substituted cyanamides (40) in the presence of hydroxylamine hydrochloride and diisopropylethylamine (DIPEA). Then, the $N$-hydroxide guanidine intermediates $(\mathbf{4 1})$ were reacted with properly substituted benzoic acids (42) in the presence of HATU and DIPEA. The two-step reaction was carried in $\mathrm{CH}_{2} \mathrm{Cl}_{2}$ at room temperature overnight, followed by reflux in 1,2-dichloroethane (DCE) for $5 \mathrm{~h}$, yielding the desired 1,2,4-oxadiazole derivatives (43) (Scheme 7). ${ }^{47}$

\subsection{Synthesis of 1,3,4-oxadiazoles}

There are several multistep and one-step protocols in the literature to the synthesis of 1,3,4-oxadiazole derivatives. Taha et al. ${ }^{39}$ reacted methyl 6-nitrobenzofuran-2-ate (44) with diazene yielding the hydrazide (45). Next, it was reacted with properly substituted aromatic acids in the presence of<smiles></smiles><smiles>[R]c1ccc2nc(N3CCOCC3)c(C(N)=NO)cc2c1</smiles>

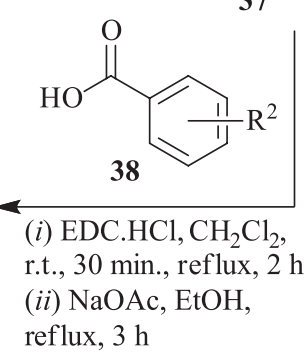

Scheme 6. Synthesis of 1,2,4-oxadiazoles (39) having antimicrobial and antifungal profiles through the coupling reaction with EDC.HCl. 


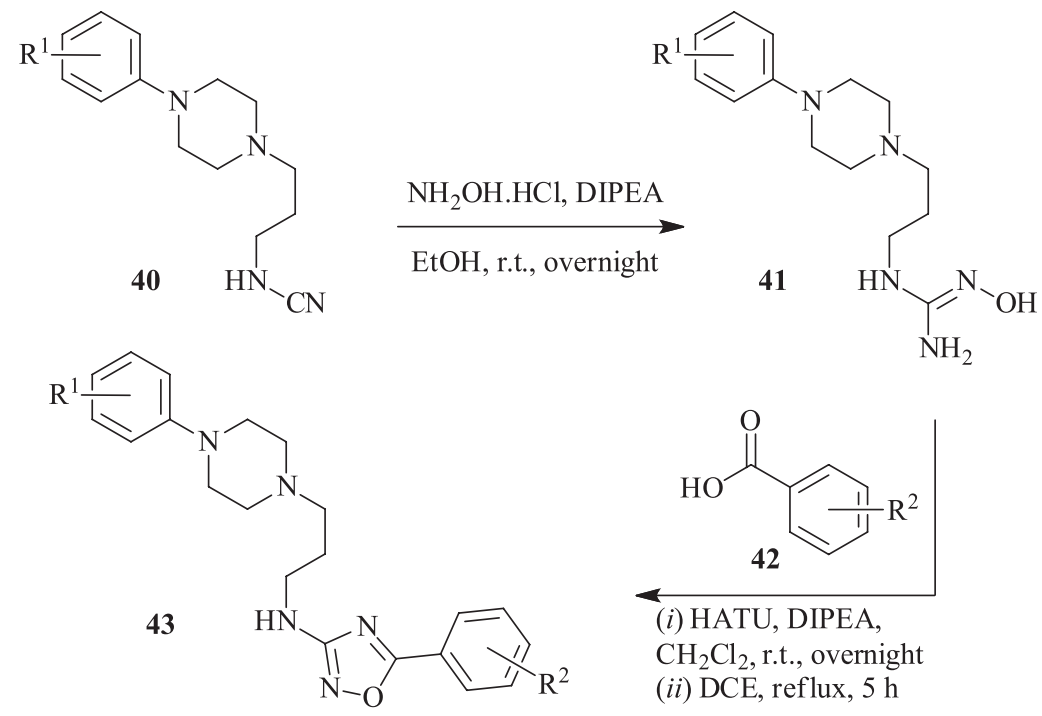

Scheme 7. Synthesis of 1,2,4-oxadiazoles (43) using the coupling reagent HATU.

phosphoryl chloride, furnishing 1,3,4-oxadiazoles (17), as shown in Scheme 8. The products were evaluated for their inhibitory activity over the enzyme $\alpha$-glucosidase. ${ }^{39}$

Zhao et $a l .{ }^{48}$ produced nonsymmetrical disulfides bearing a 1,3,4-oxadiazolic ring with antiproliferative activity. To build the 1,3,4-oxadiazole moiety the authors reacted differently substituted benzohydrazides (46) in the presence of carbon disulfide and potassium hydroxide in ethanol, yielding intermediates (47). Then, the oxadiazoles were reacted with the previously prepared $S$-alkyl-thioisothiourea intermediates (48), furnishing the disulfides (49) (Scheme 9). ${ }^{48}$

In their investigation for antitubercular agents, Desai et al. $^{49}$ obtained a 1,3,4-oxadiazole derivative through the reaction of indole-3-carbaldehyde (50) with isoniazid (51) under microwave irradiation. The<smiles>CC(C)[C@H](O)[C@H](C)N</smiles><smiles>NNC(=O)c1cc2ccc([N+](=O)[O-])cc2o1</smiles>

17

Scheme 8. Synthesis of 1,3,4-oxadiazoles (17) with antibacterial activity.<smiles>[R][R]Sc1nnc(-c2ccccc2)o1</smiles>

49<smiles>[R1]c1nnc(-c2ccccc2)o1</smiles>

47

Scheme 9. Synthesis of 1,3,4-oxadiazoles (49) with antiproliferative activity. 
intermediate $\mathbf{5 2}$ reacted with acetic anhydride under microwave irradiation yielding the 1,3,4-oxadiazole (53) (Scheme 10). ${ }^{49}$

Niu et al. ${ }^{50}$ used iodine to mediate the formation of $\mathrm{C}-\mathrm{O}$ bond in a one-pot procedure. Aldehydes with different substitution patterns (54) were reacted with semicarbazide hydrochloride in the presence of sodium acetate in methanol/water. After removing the solvents, the residue was dissolved in 1,4-dioxane followed by addition of iodine and potassium carbonate. The 1,3,4-oxadiazole derivatives (55) were obtained after $1-4.5 \mathrm{~h}$ at $80{ }^{\circ} \mathrm{C}$, as shown in Scheme 11..$^{50}$

It is also possible to find protocols employing heterogeneous catalyst systems to obtain 1,3,4-oxadiazoles in one step. Sanghshetti et al..$^{51}$ described the reaction of hydrazide (56) and several aroyl aldehydes (57) in the presence of nanoparticles of $\mathrm{ZnO}-\mathrm{TiO}_{2}$ under microwave irradiation, affording the respective 1,3,4-oxadiazoles (58). Reduced reaction times (12-15 $\mathrm{min})$ and high yields (91-96\%) are interesting features of this protocol (Scheme 12)..$^{51}$

Suresh et al..$^{52}$ described the use of $\mathrm{Al}^{3+}-\mathrm{K} 10$ clay catalyst in the reaction of hydrazides (59) and trimethyl orthoesters (60). The reaction was performed solvent-free under microwave irradiation $\left(\mathrm{T}=55^{\circ} \mathrm{C}\right)$ giving $1,3,4$-oxadiazole derivatives (61). One advantage of this protocol is the possibility of synthesizing 1,2,4-oxadiazoles (63) just by using amidoximes (62) instead of hydrazides, keeping the same experimental procedure (Scheme 13). ${ }^{52}$

Rouhani et al. ${ }^{53}$ utilized ultrasound irradiation to react aromatic carboxylic acids (64) and acenaphthoquinone (65), obtaining 1,3,4-oxadiazoles (67). The reaction was carried out in the presence of ( $N$-isocyanimino)triphenylphosphorane (66) and acetonitrile as solvent. Overall yields ranged from 67 to $85 \%$ (Scheme 14). The comparison between the procedures with and without sonication showed a significant reduction in time: 15 min with sonication versus $24 \mathrm{~h}$ without sonication. In addition, an average increase of $20 \%$ in the yields was observed when sonication was employed, corroborating the relevance of this method. ${ }^{53}$

\section{Antiparasitic Activity of Selected 1,2,4- and 1,3,4-Oxadiazoles}

1,2,4- and 1,3,4-oxadiazole rings play significant roles in medicinal chemistry and drug design. They can be found in the structure of molecules with reported bioactivity to several targets and related to a wide range of diseases. Parasitic diseases, such as trypanosomiasis, leishmaniasis, helminthiasis and ectoparasitosis, for example, form an important niche of study in this context. Such illnesses are commonly associated with poor countryside populations

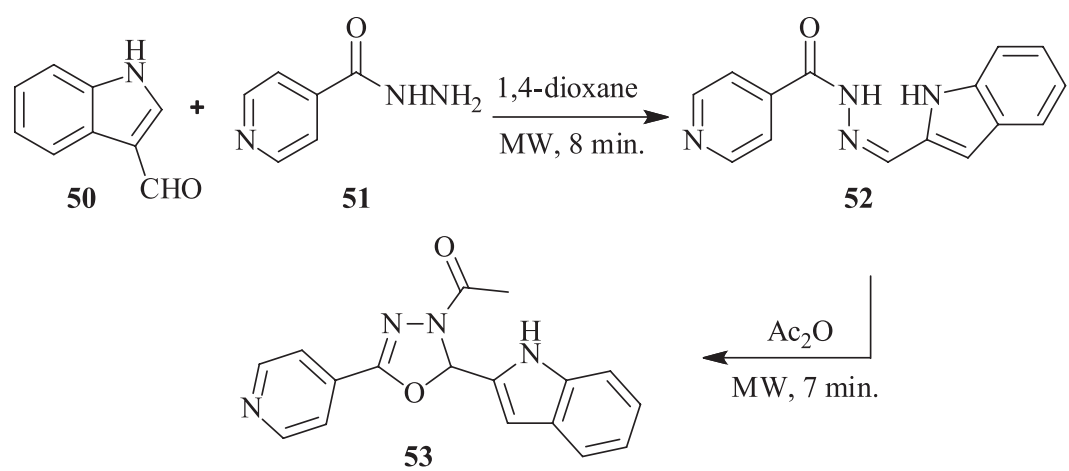

Scheme 10. Synthesis of 1,3,4-oxadiazoles (53) under microwave irradiation.<smiles>[R]C=O</smiles>

54

1) Semicarbazide hydrochloride,

$\underset{\text { 2) } \mathrm{I}_{2}, \mathrm{~K}_{2} \mathrm{CO}_{3}, 1,4 \text {-dioxane, } 80{ }^{\circ} \mathrm{C}}{\stackrel{\mathrm{AcONa}}{\mathrm{MeOH}} / \mathrm{H}_{2} \mathrm{O} \text {, r.t. }}$ $1-4.5 \mathrm{~h}$<smiles>[R]c1nnc(N)o1</smiles>

55

Scheme 11. One-pot preparation of 1,3,4-oxadiazolic derivatives (55) mediated by iodine.

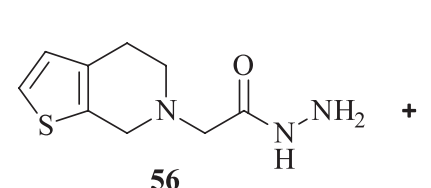

56<smiles>O=CBr</smiles>

57

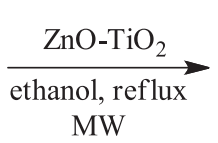

MW

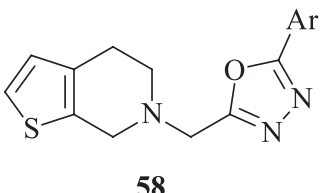

58

Scheme 12. Synthesis of 1,3,4-oxadiazoles (58), with antimicrobial activity, in the presence of $\mathrm{ZnO}-\mathrm{TiO}_{2}$ from hydrazides and aldehydes under microwave irradiation. 
<smiles>[R]c1ccc(C(=O)NN)cc1</smiles>

or<smiles>NC(=NO)c1cc[R1]cc1</smiles>

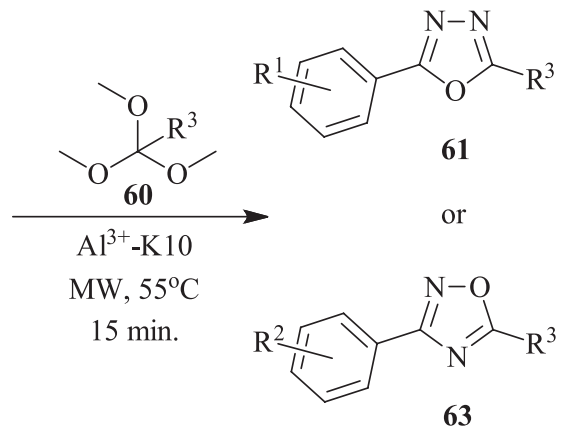

63

Scheme 13. Synthesis of 1,3,4-oxadiazoles (61) and 1,2,4-oxadiazoles (63) with $\mathrm{Al}^{3+}$-K10.

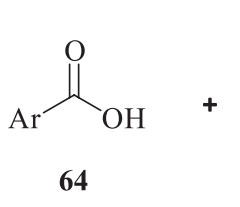

64<smiles>O=C1C(=O)c2cccc3cccc1c23</smiles>

65

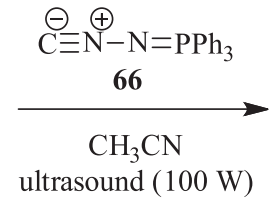

r.t., $10-15 \mathrm{~min}$.

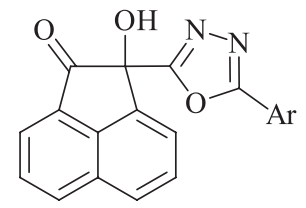

67

Scheme 14. Synthesis of 1,3,4-oxadiazoles (67) under ultrasound irradiation.

living in tropical countries. They get few research efforts from big pharmaceutical companies, which do not see the drug development for these diseases as a profitable investment. That is the reason the World Health Organization (WHO) has labeled this set of infections as neglected tropical diseases (NTDs). ${ }^{54}$

There are several reviews in the literature of 1,2,4and 1,3,4-oxadiazoles focusing on their synthesis and applications. ${ }^{55}$ In spite of that, the present work is the first review highlighting the importance of these heterocycles specifically in the development of new drugs with antiparasitic properties.

\subsection{1,2,4-Oxadiazoles as antiparasitic agents}

The first report on 1,2,4-oxadiazoles with antiparasitic activity was published in 1966 by Ainsworth et al. ${ }^{56}$ The group described the synthesis of a series of 3-substituted 1,2,4-oxadiazoles and their anthelmintic activity in different in vivo infected rodent models. The most potent derivative was 3-p-chlorophenyl-1,2,4-oxadiazole, 68 (Table 1). It reduced the Nematospiroides dubius worm count by $94 \%$ when administered orally ( $100 \mathrm{mg} \mathrm{kg}^{-1}$, single dose) and by $100 \%$ when injected subcutaneously $\left(500 \mathrm{mg} \mathrm{kg}^{-1}\right.$, single dose). Compound $\mathbf{6 8}$ was also assayed for anthelmintic activity against Nippostrongylus muris $\left(250 \mathrm{mg} \mathrm{kg}^{-1}\right.$, oral dose, $100 \%$ efficacy), Syphacia obvelata $\left(1000 \mathrm{mg} \mathrm{kg}^{-1}\right.$, oral dose, 90\% efficacy), Strongyloides ratti (1000 $\mathrm{mg} \mathrm{kg}^{-1}$, oral dose, active), and Trichostrongylus axei (250 $\mathrm{mg} \mathrm{kg}^{-1}$, oral dose, active). ${ }^{56}$

Haugwitz et al. ${ }^{57}$ reported the anthelmintic activity of a series of novel isothiocyanatophenyl-1,2,4-oxadiazoles against $N$. dubius and Hymenolepis nana in infected mice. The results showed the most potent compounds of the series against $H$. nana were 69 and 70a-c (Table 2). The drugs displayed $100 \%$ efficacy after a $100 \mathrm{mg} \mathrm{kg}^{-1}$ single-dose treatment. Compounds 69 and 70a were the most potent against $N$. dubius under the same drug regimen, with efficacies of $100 \%$ and $90 \%$, respectively. Anthelmintic efficacy was also determined in sheep naturally infected with a mixed gastrointestinal nematode population. A $100 \%$ efficacy, determined by fecal egg count, was observed after oral administration of 69 (100 mg kg-1, a single dose). Compounds 70a and $\mathbf{7 0 b}$, at the same drug regimen, displayed efficacies of 99 and 73\%, respectively. Compound 70c was inactive to mixed gastrointestinal nematodes in sheep. Compound 69 also showed 100\% efficacy against Ancylostoma caninum in infected dogs treated with a single oral dose at $200 \mathrm{mg} \mathrm{kg}^{-1}$. The authors pointed out the presence of the isothiocyanatophenyl moiety at the 3-position of 1,2,4-oxadiazolic ring as an important feature to anthelmintic activity..$^{57}$

Cottrell et al..$^{58}$ designed a series of analogues based on the structure of WR85915 (71)..$^{58}$ The prototype had been previously described as a tubulin inhibitor tested

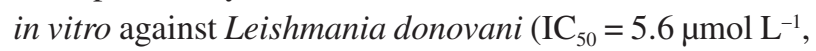
promastigotes; $\mathrm{IC}_{50}=4.3 \mu \mathrm{mol} \mathrm{L}{ }^{-1}$, axenic amastigotes). ${ }^{59}$ The new molecules were assayed for antiprotozoal activity against $L$. donovani and Trypanosoma brucei. Compound 72a (Table 3) displayed the best antiparasitic profile to both $L$. donovani $\left(\mathrm{IC}_{50}=2.3 \mu \mathrm{mol} \mathrm{L} \mathrm{L}^{-1}\right.$, axenic amastigotes) and T. brucei $\left(\mathrm{IC}_{50}=5.2 \mu \mathrm{mol} \mathrm{L}{ }^{-1}\right.$, variant 221). On the other hand, it displayed variable 
Table 1. First reported 1,2,4-oxadiazole (68) with anthelmintic activity

\begin{tabular}{|c|c|c|c|c|}
\hline & & 68 & & \\
\hline Infectious species & Oral dose $/\left(\mathrm{mg} \mathrm{kg}^{-1}\right)$ & Anthelmintic efficacy / \% & Subcutaneous dose $/\left(\mathrm{mg} \mathrm{kg}^{-1}\right)$ & Anthelmintic efficacy / \% \\
\hline \multirow[t]{2}{*}{ N. dubius } & 50 & 63 & 100 & 0 \\
\hline & 100 & 94 & 500 & 100 \\
\hline \multirow[t]{2}{*}{ N. muris } & 50 & 75 & 1000 & 100 \\
\hline & 100 & 100 & & \\
\hline \multirow[t]{2}{*}{ S. obvelata } & 500 & 0 & - & - \\
\hline & 1000 & 90 & & \\
\hline S. ratti & 1000 & active & 1000 & active \\
\hline T. axei & 250 & active & - & - \\
\hline
\end{tabular}

Table 2. Structure of 1,2,4-oxadiazoles with nematocidal and taeniacidal activity (69 and 70a-c) and against A. caninum (hookworms) (69)

\begin{tabular}{|c|c|c|c|c|c|c|c|}
\hline \multirow[t]{2}{*}{ Compound } & \multirow[t]{2}{*}{$\mathrm{R}^{1}$} & \multirow[t]{2}{*}{$\mathrm{R}^{2}$} & \multirow[t]{2}{*}{$\mathrm{R}^{3}$} & \multicolumn{2}{|c|}{$\begin{array}{l}\text { Efficacy in infected mice } \\
\left(100 \mathrm{~m} \mathrm{~kg}^{-1} \text {,oral }\right) / \%\end{array}$} & \multirow{2}{*}{$\begin{array}{l}\text { Efficacy in naturally } \\
\text { infected sheep } \\
\left(100 \mathrm{mg} \mathrm{kg}^{-1} \text {, oral }\right) / \%\end{array}$} & \multirow{2}{*}{$\begin{array}{c}\text { Efficacy in dogs infected } \\
\text { with A. caninum } \\
\text { (200 } \mathrm{mg} \mathrm{kg}^{-1} \text {, oral) /\% }\end{array}$} \\
\hline & & & & H. nana & N. dubious & & \\
\hline 69 & - & - & - & 100 & 100 & 100 & 100 \\
\hline $70 a$ & $-\mathrm{NCS}$ & $-\mathrm{H}$ & $-\mathrm{H}$ & 100 & 90 & 99 & - \\
\hline $70 \mathrm{~b}$ & -NCS & $-\mathrm{H}$ & $-\mathrm{Cl}$ & 100 & 0 & 73 & - \\
\hline $70 \mathrm{c}$ & $-\mathrm{Cl}$ & $-\mathrm{NCS}$ & $-\mathrm{H}$ & 100 & 0 & 0 & - \\
\hline
\end{tabular}

cytotoxicity values against mammalian cell lines (J774, PC3 and Vero cells). It influenced the selectivity indexes (SIs), which is the ratio between $\mathrm{IC}_{50}$ values against mammalian cells and protozoan. The authors observed a positive correlation between the lipophilicity of the 3 -aryl ring and the antileishmanial activity. It was also observed that derivatives with an alkyl chain in the C5 of 1,3,4-oxadiazolic ring (72b-c) were ineffective against the different protozoan species assayed. It suggests that the 5-thioisocyanatomethyl group is an important feature for antikinetoplastid activity of this series (Table 3). ${ }^{58}$

The prototype compound WR85915 (71), for its part, confirmed its activity against protozoan $\left(\mathrm{IC}_{50}=4.5 \mu \mathrm{mol} \mathrm{L}{ }^{-1}\right.$, axenic amastigotes of $L$. donovani; $\mathrm{IC}_{50}=5.2 \mu \mathrm{mol} \mathrm{L}{ }^{-1}$, variant 221 of $T$. brucei) and displayed lower cytotoxic profile against mammalian cell lines. These results justified the antiprotozoal studies of $\mathbf{7 1}$ in vivo in a rodent model (BALB/c mice) of visceral leishmaniasis. In comparison with reference drugs pentostam and pentamidine, compound 71 displayed good inhibition values of liver parasitemia, as shown in Table $4 .^{58}$

Santos-Filho et al. ${ }^{60}$ described the synthesis, biological activity and docking results of a series of 3-(4-substitutedaryl)-1,2,4-oxadiazoles- $N$-acylhydrazones as antiTrypanosoma cruzi agents. The in vitro assessment for antiprotozoal activity was conducted against trypomastigotes of T. cruzi (Y strain). Compounds 73a and 73b displayed higher potency than benznidazole, the reference drug for the treatment of Chagas disease $\left(\mathrm{IC}_{50}\right.$ values of 3.6 and $3.9 \mu \mathrm{mol} \mathrm{L}^{-1}$ for $\mathbf{7 3 a}$ and $\mathbf{7 3 b}$, respectively; $\mathrm{IC}_{50}=5.0 \mu \mathrm{mol} \mathrm{L} \mathrm{L}^{-1}$ for benznidazole). In addition, 73a and $\mathbf{7 3 b}$ were also assayed in vitro for cytotoxicity against $\mathrm{BALB} / \mathrm{c}$ mouse splenocytes. The results showed moderate to high selectivity in comparison with a mammalian model ( $\mathrm{SI}=26.4$ and 7.7 for $\mathbf{7 3 a}$ and $\mathbf{7 3 b}$, respectively). A docking study was realized with an in silico model for cruzain (PDB code: 1U9Q). ${ }^{60}$ This cysteine protease is known to participate in several biological processes of the parasite, 
Table 3. Structure and $\mathrm{IC}_{50}$ values of 1,2,4-oxadiazoles (71, 72a-c) against $L$. donovani and $T$. brucei and cytotoxicity to mammalian cell lines (J774, PC3 and Vero, not defined for $\mathbf{7 2 b}-\mathbf{c})$

\begin{tabular}{|c|c|c|c|c|c|c|c|}
\hline & & & 71 & & & & \\
\hline \multirow{2}{*}{ Compound } & \multirow{2}{*}{$\mathrm{R}^{1}$} & \multirow{2}{*}{$\mathrm{R}^{2}$} & \multicolumn{5}{|c|}{$\mathrm{IC}_{50} /(\mu \mathrm{mol} \mathrm{L}-1)$} \\
\hline & & & L. donovani & T. brucei & $\mathrm{J} 774$ & $\mathrm{PC} 3$ & Vero cells \\
\hline 71 & - & - & $4.5 \pm 1.8$ & $5.2 \pm 1.7$ & $29 \pm 7$ & $17 \pm 6$ & $41 \pm 14$ \\
\hline $72 a$ & $3,4-\mathrm{Cl}_{2}$ & $\mathrm{SCN}$ & $2.3 \pm 1.0$ & $5.2 \pm 2.0$ & $17 \pm 2$ & $3.9 \pm 2.2$ & $70 \pm 22$ \\
\hline $72 b$ & $\mathrm{H}$ & ${ }^{\mathrm{i}} \mathrm{Pr}$ & $>200$ & $>25$ & - & - & - \\
\hline $72 c$ & $4-\mathrm{Cl}$ & ${ }^{\mathrm{i}} \mathrm{Pr}$ & $>200$ & $>25$ & - & - & - \\
\hline
\end{tabular}

Table 4. Activity of 71, pentostam and pentamidine against $L$. donovani in $\mathrm{BALB} / \mathrm{c}$ mice

\begin{tabular}{|c|c|c|c|}
\hline Compound & Dosing regimen & $\begin{array}{l}\text { Actual dose } \\
\text { received } / \mathrm{mg}\end{array}$ & $\begin{array}{l}\text { Inhibition } \pm \\
\text { S.E.M. / \% }\end{array}$ \\
\hline \multicolumn{4}{|c|}{ Experiment 1} \\
\hline 71 & $\begin{array}{l}5 \mathrm{mg} \mathrm{kg}^{-1} \\
\text { i.v. } \times 5\end{array}$ & 2.5 & $48 \pm 8$ \\
\hline Pentostam & $\begin{array}{l}15 \mathrm{mg} \mathrm{kg}^{-1} \\
\text { s.c. } \times 5\end{array}$ & 7.5 & $60 \pm 5$ \\
\hline Pentamidine & $\begin{array}{l}5 \mathrm{mg} \mathrm{kg}^{-1} \\
\text { i.v. } \times 5^{\text {a }}\end{array}$ & $1.5^{\mathrm{a}}$ & $41 \pm 14$ \\
\hline \multicolumn{4}{|c|}{ Experiment 2} \\
\hline 71 & $\begin{array}{l}5 \mathrm{mg} \mathrm{kg}^{-1} \\
\text { i.v. } \times 5^{\mathrm{b}}\end{array}$ & $25^{\mathrm{b}}$ & $61 \pm 8$ \\
\hline Pentostam & $\begin{array}{l}15 \mathrm{mg} \mathrm{kg}^{-1} \\
\text { s.c. } \times 5\end{array}$ & 7.5 & $47 \pm 5$ \\
\hline
\end{tabular}

aPentamidine produced irritation on administration of full dose on day 1 . The dose was reduced by $50 \%$ for all mice for the following 4 days; ${ }^{b}$ a slight loss of weight in this group of mice was observed. i.v.: intravenous; s.c.: subcutaneous; S.E.M.: standard error of the mean.

such as proteolysis, cellular invasion and host immune system evasion. ${ }^{61}$ The docking scores observed for the most potent molecules of the series indicate their main mechanism of action could be related to cruzain inhibition. Chemical structures, $\mathrm{IC}_{50}$ values against trypomastigote of T. cruzi (Y strain), cytotoxicity against mouse splenocytes (maximum noncytotoxic concentration), SIs and docking scores (GOLD) for compounds 73a-b and benznidazole are shown in Table $5 .{ }^{60}$

A work published by Dürüst et al. ${ }^{62}$ in 2012 described the synthesis of a series of novel compounds containing both 1,2,4-oxadiazole and 1,2,3-triazole heterocyclic rings. The molecules were assayed in vitro for antiprotozoal activity against T. brucei rhodesiense (bloodstream forms, STIB 900 strain), T. cruzi (intracellular amastigotes in L6 cells,
Tulahuen strain C2C4), L. donovani (axenic amastigotes, MHOM/ET/67/L82 strain) and Plasmodium falciparum (erythrocytic stages, K1 strain). Cytotoxicity was measured against mammalian cells (L6 rat myoblasts cell line) and SI's were calculated for this review. Results showed that compound 74a was the most active against both $T$. b. rhodesiense $\left(\mathrm{IC}_{50}=7.0 \mu \mathrm{g} \mathrm{mL} L^{-1}\right.$, $\left.\mathrm{SI}=6.8\right)$ and $L$. donovani $\left(\mathrm{IC}_{50}=1.6 \mu \mathrm{g} \mathrm{mL} \mathrm{m}^{-1}\right.$, $\left.\mathrm{SI}=29.6\right)$. The most active compound against $P$. falciparum was $\mathbf{7 4 b}$ $\left(\mathrm{IC}_{50}=13.2 \mu \mathrm{g} \mathrm{mL} \mathrm{L}^{-1}, \mathrm{SI}=1.2\right)$, which also showed moderate activity towards $T$. $b$. rhodesiense $\left(\mathrm{IC}_{50}=8.4 \mu \mathrm{g} \mathrm{mL}-1\right.$, $\mathrm{SI}=1.8)$ and $L$. donovani $\left(\mathrm{IC}_{50}=2.2 \mu \mathrm{g} \mathrm{mL}-1, \mathrm{SI}=6.9\right)$. However, its toxicity to the mammalian cell line L6 $\left(\mathrm{IC}_{50}=15.2 \mu \mathrm{g} \mathrm{mL} \mathrm{L}^{-1}\right)$, and consequent low selectivity, indicates it can be harmful to both parasite and host. Compound 74c figured as one most active of the series in addition to display the highest SI values when assayed against $T$. b. rhodesiense $\left(\mathrm{IC}_{50}=8.0 \mu \mathrm{g} \mathrm{mL}-1\right.$, $\left.\mathrm{SI}>12.5\right)$, L. donovani $\left(\mathrm{IC}_{50}=2.0 \mu \mathrm{g} \mathrm{mL} \mathrm{g}^{-1}, \mathrm{SI}>50\right)$ and $P$. falciparum $\left(\mathrm{IC}_{50}=14.7 \mu \mathrm{g} \mathrm{mL}-1, \mathrm{SI}>6.8\right)$. None of the molecules displayed $\mathrm{IC}_{50}$ values lower than $30 \mu \mathrm{g} \mathrm{mL} \mathrm{m}^{-1}$ against T. cruzi. The halogen substitution at para position (74e-f) of phenyl group attached to oxadiazole ring have little impact on antiprotozoal activity. On the other hand, it was observed that fluorination (74d) affects selectivity, once the fluorinated derivative showed no toxicity to L6 cells at $100 \mu \mathrm{g} \mathrm{mL} \mathrm{L}^{-1}$. Compounds 74a-f chemical structures and the respective in vitro results are shown in Table $6 .{ }^{62}$

A later work by Santos-Filho et al. ${ }^{63}$ in 2016, described the synthesis and antimalarial activity of a series of $N$-acylhydrazone-1,2,4-oxadiazoles derivatives (75). The compounds were assessed in vitro against chloroquineresistant W2 strain of blood stage P. falciparum and for cytotoxicity against human cell line HepG2. The standard drug mefloquine was used as a positive control and SI values calculated in all cases based on the $\mathrm{IC}_{50}$ values 
Table 5. Chemical structures, $\mathrm{IC}_{50}$ values against trypomastigotes, cytotoxicity against BALB/c mouse splenocytes and GOLD scores for cruzain docking of 1,2,4-oxadiazoles (73a-b)

\begin{tabular}{|c|c|c|c|c|c|}
\hline Compound & $\mathrm{R}$ & Trypomastigotes $\mathrm{IC}_{50} /(\mu \mathrm{mol} \mathrm{L}-1)$ & Cytotoxicity / $\left(\mu \mathrm{mol} \mathrm{L}{ }^{-1}\right)$ & SI & GOLD score \\
\hline $73 \mathbf{a}$ & $-\mathrm{H}$ & 3.6 & 95 & 26.4 & 45.08 \\
\hline $73 b$ & $-\mathrm{Me}$ & 3.9 & 30 & 7.7 & 46.62 \\
\hline Benznidazole & - & 5.0 & 100 & 20 & 43.83 \\
\hline
\end{tabular}

SI: selectivity index.

Table 6. Chemical structure, $\mathrm{IC}_{50}$ values for antiprotozoal assays and cytotoxicity against L6 rat skeletal myoblast cells of novel 1,2,4-oxadiazoles (74a-f)

\begin{tabular}{|c|c|c|c|c|c|c|}
\hline \multirow[b]{2}{*}{ Compound } & \multirow[b]{2}{*}{$\mathrm{R}$} & \multicolumn{5}{|c|}{$\mathrm{IC}_{50} /\left(\mu \mathrm{g} \mathrm{mL}^{-1}\right)$} \\
\hline & & T. brucei rhodesiense & T. cruzi & L. donovani & P. falciparum & $\begin{array}{l}\text { Cytotoxicity } \\
\text { L6 cells }\end{array}$ \\
\hline $74 a$ & $-\mathrm{H}$ & 7.0 & 46.1 & 1.6 & 22.6 & 47.3 \\
\hline $74 \mathrm{~b}$ & $-\mathrm{Me}$ & 8.4 & 38.9 & 2.2 & 13.2 & 15.2 \\
\hline $74 \mathrm{c}$ & $-\mathrm{NO}_{2}$ & 8.0 & 41.1 & 2.0 & 14.7 & $>100$ \\
\hline 74d & $-\mathrm{F}$ & 12.3 & 62.4 & 4.1 & 23.6 & $>100$ \\
\hline $74 e$ & $-\mathrm{Cl}$ & 17.2 & 49.0 & 3.2 & 24.9 & 49.5 \\
\hline 74f & $-\mathrm{Br}$ & 18.2 & 54.9 & 3.5 & 26.9 & 58.6 \\
\hline Standard & - & $0.005^{\mathrm{a}}$ & $0.464^{\mathrm{b}}$ & $0.171^{\mathrm{c}}$ & $0.073^{\mathrm{d}}$ & $0.007^{\mathrm{e}}$ \\
\hline
\end{tabular}

${ }^{\mathrm{a}}$ Melarsoprol; ${ }^{\mathrm{b}}$ benznidazole; ${ }^{\mathrm{c}}$ miltefosine; ${ }^{\mathrm{d}}$ chloroquine; ${ }^{\mathrm{e}}$ podophyllotoxin.

observed, as shown in Table 7. Compound $\mathbf{7 5 b}$ displayed the lowest $\mathrm{IC}_{50}$ value $\left(0.07 \mu \mathrm{mol} \mathrm{L}{ }^{-1}\right)$, similar to mefloquine $\left(0.04 \mu \mathrm{mol} \mathrm{L}{ }^{-1}\right)$, followed by $75 \mathbf{a}\left(\mathrm{IC}_{50}=0.12 \mu \mathrm{mol} \mathrm{L} \mathrm{L}^{-1}\right)$ and 75c $\left(\mathrm{IC}_{50}=0.20 \mu \mathrm{mol} \mathrm{L}{ }^{-1}\right)$. Compounds 75d-e presented $\mathrm{IC}_{50}$ values 37.5 to 47.5 -fold lower than the standard drug, but their low cytotoxicity to human HepG2 cells is an interesting result. In addition, in vivo studies were conducted on Swiss mice (groups of $\mathrm{n}=5$ ) infected with Plasmodium berghei (NK65 strain) to determine the influence of the treatment on blood parasitemia and survival rates. The drug candidates with lowest $\mathrm{IC}_{50}$ values (75a-c) on the in vitro tests were selected to this evaluation and compared with the standard drug chloroquine. At $50 \mathrm{mg} \mathrm{kg}^{-1} \mathrm{day}^{-1}$ for 4 days, administered orally, none of the test compounds (75a-c) could either reduce parasitemia (after 8 days) or improve survival rates (after 30 days). Under the same drug regimen, but administered intraperitoneally, only 75c reduced parasitemia ( $0 \%$ ) compared with the vehicle $(10 \%$ DMSO (dimethyl sulfoxide) on saline, $50 \%$ parasitemia). On the other hand, the survival rate for animals treated with 75c was only $50 \%$, which indicates the drug could have toxic effects towards the host. Treatment with chloroquine both orally and intraperitoneally led to $0 \%$ parasitemia and $100 \%$ survival rate. The in vivo results presented on Table 7 refer to $50 \mathrm{mg} \mathrm{kg}^{-1}$ day $^{-1}$ drug regimen (4 days) administered intraperitoneally. ${ }^{63}$

\subsection{1,3,4-Oxadiazoles as antiparasitic agents}

An early work by Hutt et al..$^{64}$ described the synthesis of a series of differently substituted 2-trichloromethyl5-phenyl-1,3,4-oxadiazoles. The compounds were inspired by the chemical structure of 1,4-bis-(trichloromethyl) benzene (76, hetol), based on previous reports of its 
Table 7. Chemical structure and biological assessment results for antimalarial activity of 1,2,4-oxadiazoles (75a-e)

\begin{tabular}{|c|c|c|c|c|c|c|c|}
\hline \multirow{2}{*}{ Compound } & \multirow{2}{*}{$\mathrm{R}^{1}$} & \multirow{2}{*}{$\mathrm{R}^{2}$} & \multicolumn{2}{|c|}{$\mathrm{IC}_{50} \pm \mathrm{SD} /\left(\mu \mathrm{mol} \mathrm{L}{ }^{-1}\right)$} & \multirow{2}{*}{$\mathrm{SI}^{\mathrm{b}}$} & \multicolumn{2}{|c|}{$\begin{array}{c}\text { In vivo assessment } \\
\left(50 \mathrm{mg} \mathrm{kg}^{-1} \text { day }^{-1} \text {, i.p. }{ }^{\mathrm{c}}\right)\end{array}$} \\
\hline & & & $\begin{array}{l}\text { P. falciparum } \\
\text { (W2 strain) }\end{array}$ & $\begin{array}{l}\text { Cytotoxicity } \\
\text { HepG2 cells }\end{array}$ & & $\begin{array}{c}\text { P. berghei } \\
\text { parasitemia }^{\mathrm{d}} / \%\end{array}$ & Survival rate $/ \%$ \\
\hline $75 a$ & $-\mathrm{Me}$ & 3-MeO, 4-OH & $0.12 \pm 0.16$ & $46.6 \pm 0.5$ & 388 & 40 & 0 \\
\hline $75 b$ & $-\mathrm{Br}$ & 3-MeO, 4-OH & $0.07 \pm 0.12$ & $16.9 \pm 1.9$ & 241 & 40 & 0 \\
\hline $75 \mathrm{c}$ & $-\mathrm{NO}_{2}$ & 3-MeO, 4-OH & $0.20 \pm 0.16$ & $14.8 \pm 0.8$ & 74 & 0 & 50 \\
\hline $75 \mathrm{~d}$ & $-\mathrm{OH}$ & 3-MeO, 4-OH & $1.90 \pm 0.08$ & $>200$ & - & - & - \\
\hline $75 e$ & $-\mathrm{OH}$ & 3,4-dioxymethylene & $1.50 \pm 1.09$ & $>200$ & - & - & - \\
\hline Standard $^{\mathrm{a}}$ & - & - & $0.04 \pm 0.16$ & $11.8 \pm 0.3$ & 295 & 0 & 100 \\
\hline
\end{tabular}

${ }^{\mathrm{a}}$ Mefloquine (in vitro) or chloroquine (in vivo); ${ }^{\mathrm{b}}$ selectivity index; ${ }^{\mathrm{c}}$.p.: intraperitoneal; ${ }^{\mathrm{d}}$ calculated 8 days after the infection in comparison with the nontreated group; ${ }^{\text {ccalculated }} 30$ days after the infection in comparison with the nontreated group.

antimalarial activity in infected monkeys. ${ }^{65}$ Test molecules were assayed for antimalarial activity in BALB/c mice infected with $P$. berghei ( $\mathrm{n}=5$ groups). The animals were treated with a single subcutaneous dose of test compounds $\left(640,320,160\right.$ and $\left.80 \mathrm{mg} \mathrm{kg}^{-1}\right)$ and compared with hetol at the same drug regimen. Compounds 77a-b displayed the highest cure rates $(60-80 \%)$ and extension of mean survival times ( $\triangle \mathrm{MST}$, days) in comparison with nontreated controls. It was observed $100 \%$ cure rate in animals treated with hetol. The series of 1,3,4-oxadiazoles was also tested for antimalarial activity against Plasmodium gallinaceum in chicks. Test compounds were administered subcutaneously in a single dose. Only compound $77 \mathbf{c}$ led to cure (60\% at $240 \mathrm{mg} \mathrm{kg}^{-1}$ ). Chemical structures and biological evaluation results for compounds 77a-c and hetol are shown in Table 8. The events of cure are represented by $\mathrm{C}(\mathrm{n})$, while the deaths due to drug toxicity are represented by $\mathrm{T}(\mathrm{n})$, where $\mathrm{n}=$ frequency. ${ }^{64}$

More recently, Balaji et al. ${ }^{66}$ reported the synthesis and antimalarial evaluation of 20 novel 1,3,4-oxadiazole derivatives. The compounds were assayed against chloroquine-sensitive (NF54) and chloroquine-resistant

Table 8. 1,3,4-Oxadiazoles 77a-c with reported antimalarial activity

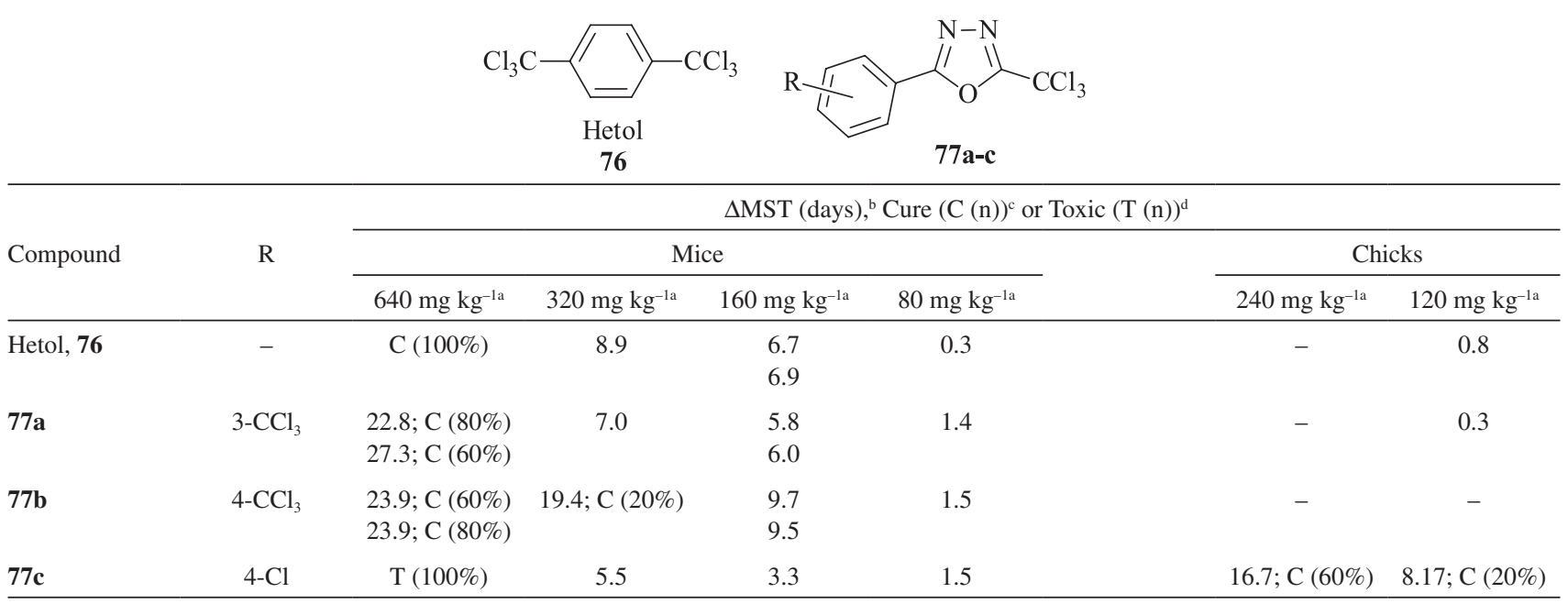

a Single s.c. dose in $\mathrm{mg} \mathrm{kg}^{-1}$, milligrams of drug administered subcutaneously per kilogram of animal's body weight; five animals used per dosage level; ${ }^{b}$ calculated by subtraction of mean survival times (MST) of untreated control from treated situations; ${ }^{~}$ cure defined by survival 60 or 30 days after infection for mice and chicks, respectively, $\mathrm{n}$ stands for the frequency of the event; deaths occurred within $48 \mathrm{~h}$ after drug administration; $\mathrm{n}$ stands for the frequency of the event. 
(Dd2) strains of $P$. falciparum. Submicromolar $\mathrm{IC}_{50}$ values were observed for both strains. We highlight here the results for five derivatives (78a-e, Table 9). The compounds displayed comparable (NF54) or higher (Dd2) toxicity to parasites compared with reference drug chloroquine. Based on the full series of compounds tested, the authors indicated the importance of the imidazole ring and the bromine atom to the antimalarial activity. ${ }^{66}$

Das et al. ${ }^{67}$ reported in 1980 the synthesis and biological assessment of 1,3,4-oxadiazoles and other 5-membered heterocycles designed similarly to 3,4-dimethyl2,5-bis(4-guanylphenyl)-furan (79), previously reported as a potent antitrypanosomal molecule. ${ }^{68}$ Antiparasitic activity of test compounds was determined against $T$. brucei rhodesiense in infected $\mathrm{BALB} / \mathrm{c}$ mice ( $\mathrm{n}=5$ groups). Among the active molecules, 1,3,4-oxadiazole 80 (Table 10) displayed a $100 \%$ cure rate at $26.5 \mathrm{mg} \mathrm{kg}^{-1}$.
However, it showed toxicity to the mammalian host at higher doses. ${ }^{67}$

Patel et al.${ }^{69}$ described the synthesis, characterization and anthelmintic activity of a series of 1,3,4-oxadiazoles. Biological assessments were performed against earthworms (Perituma posthuma) in saline solution, having albendazole as reference drug. Paralysis and death times were measured respectively as the necessary times for earthworms to become motionless and to be inert to external stimuli. Compounds 81b, d, e and 82a-d displayed significant paralytic times, while compounds 81a-e showed better lethal times than that observed for the standard drug. Compound 81e displayed better paralysis and death times than albendazole. The chemical structures of compounds 81a-e and 82a-d are shown in Figure 14 and the biological activities against $P$. posthuma are given in Table $11 .^{69}$

Table 9. Chemical structures and antimalarial (P. falciparum, NF54 and Dd2 strains) results for 1,3,4-oxadiazoles (78a-e)

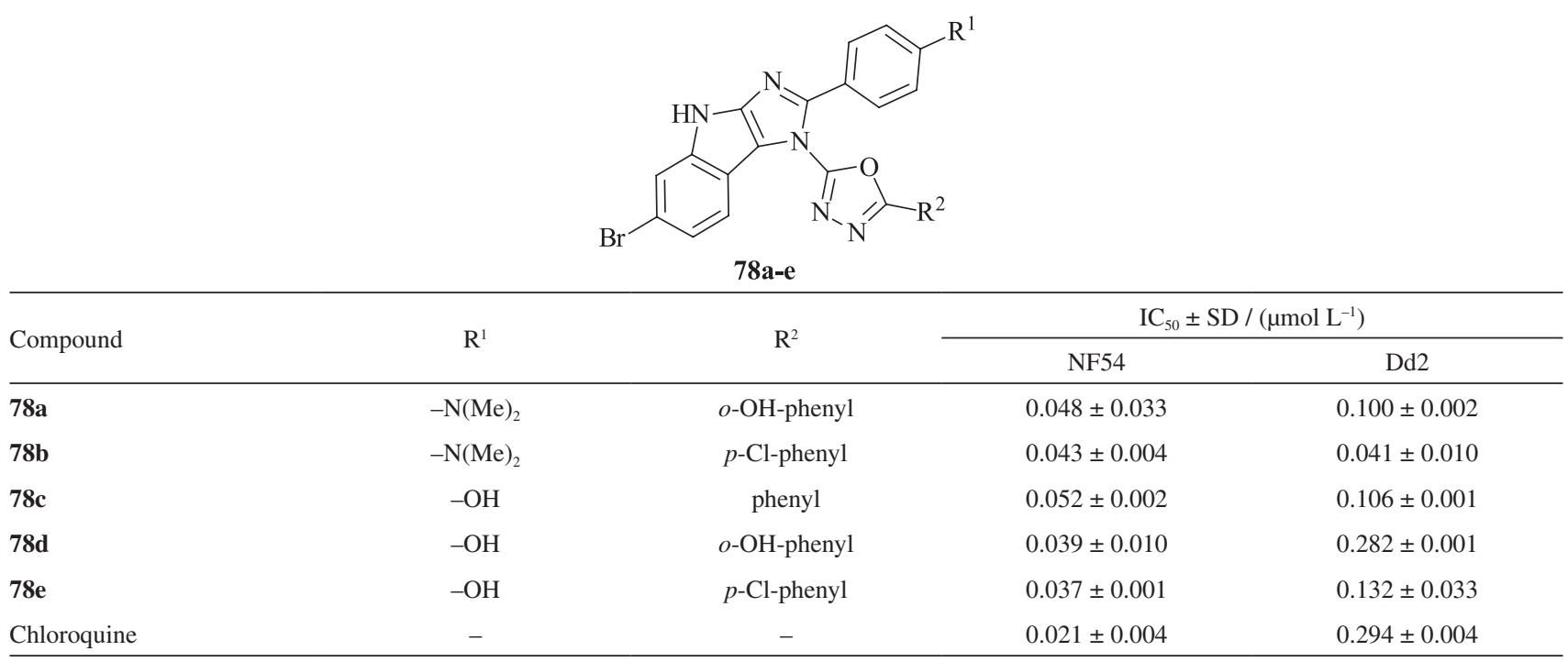

Table 10. Comparison between the antitrypanosomal activity (T. brucei rhodesiense) of prototype compound 79 and 1,3,4-oxadiazole $\mathbf{8 0}$

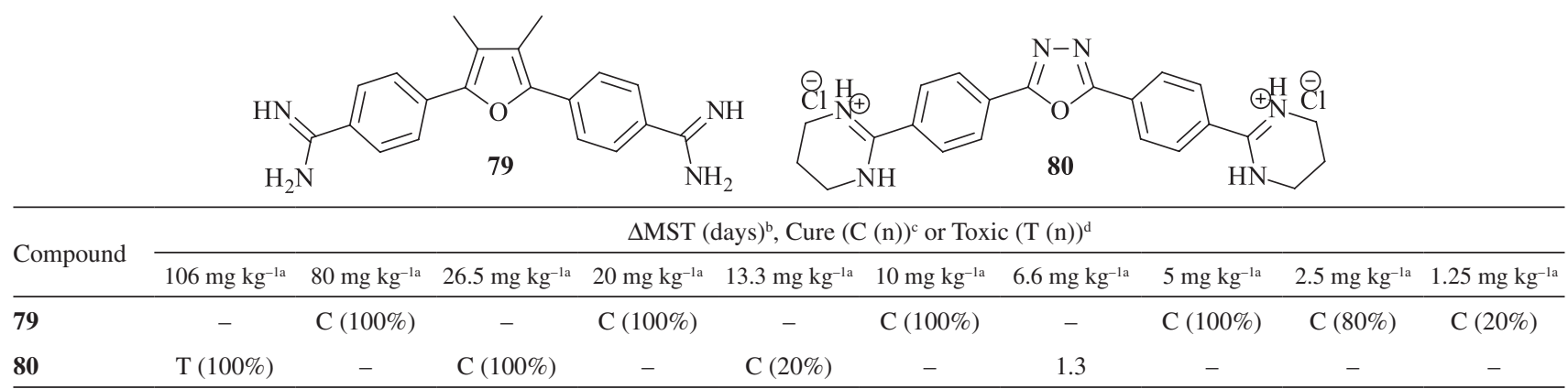

a Single s.c. dose in $\mathrm{mg} \mathrm{kg}^{-1}$, milligrams of drug administered subcutaneously per kilogram of animal's body weight, five animals used per dosage level; ${ }^{\mathrm{b}}$ calculated by subtraction of mean survival times (MST) of untreated control from treated situations; ${ }^{\mathrm{c}}$ cure defined by survival 60 days after infection; $\mathrm{n}$ stands for the frequency of the event; ${ }^{\mathrm{d}}$ deaths occurred within $48 \mathrm{~h}$ after drug administration; $\mathrm{n}$ stands for the frequency of the event. 


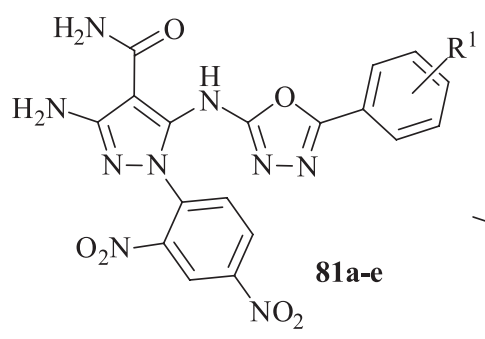<smiles>[R20]c1ccccc1-c1nnc(N2C(=O)/C(=C/c3ccc(N(C)C)cc3)N=C2c2ccccc2)o1</smiles>

$\mathbf{R}^{1} \quad \mathbf{R}^{1}$

$\begin{array}{ll}\text { 81a } 2-\mathrm{Cl} & \text { 81d } 4-\mathrm{MeO} \\ \text { 81b } 4-\mathrm{N}\left(\mathrm{CH}_{3}\right)_{2} & \text { 81e } 2-\mathrm{OH} \\ \text { 81c } & 3-\mathrm{NO}_{2}\end{array}$

$\mathbf{R}^{2} \quad \mathbf{R}^{2}$

$82 \mathrm{a}-\mathrm{H} \quad 82 \mathrm{c} 3-\mathrm{NO}_{2}$

82b $4-\mathrm{N}\left(\mathrm{CH}_{3}\right)_{2} \quad \mathbf{8 2 d} 4-\mathrm{MeO}$

Figure 14. Structures of anthelmintic 1,3,4-oxadiazole derivatives 80a-e and 81a-d.

Table 11. Anthelmintic activity of compounds 81a-e and 82a-d

\begin{tabular}{|c|c|c|c|}
\hline \multirow{2}{*}{ Situation } & \multirow{2}{*}{$\begin{array}{c}\text { Concentration / } \\
\% \mathrm{~m} / \mathrm{v}\end{array}$} & \multicolumn{2}{|c|}{ time / min } \\
\hline & & For paralysis & For death \\
\hline Control & - & - & - \\
\hline \multirow{3}{*}{ Albendazole } & 0.075 & 7 & 25 \\
\hline & 0.150 & 3 & 20 \\
\hline & 0.225 & 2 & 16 \\
\hline \multirow{3}{*}{$81 \mathrm{a}$} & 0.075 & 9 & 44 \\
\hline & 0.150 & 6 & 24 \\
\hline & 0.225 & 5 & 13 \\
\hline \multirow{3}{*}{$81 b$} & 0.075 & 7 & 30 \\
\hline & 0.150 & 5 & 20 \\
\hline & 0.225 & 3 & 11 \\
\hline \multirow{3}{*}{$81 c$} & 0.075 & 9 & 37 \\
\hline & 0.150 & 7 & 16 \\
\hline & 0.225 & 4 & 13 \\
\hline \multirow{3}{*}{ 81d } & 0.075 & 6 & 32 \\
\hline & 0.150 & 5 & 26 \\
\hline & 0.225 & 3 & 14 \\
\hline \multirow{3}{*}{$81 e$} & 0.075 & 5 & 25 \\
\hline & 0.150 & 3 & 20 \\
\hline & 0.225 & 2 & 12 \\
\hline \multirow{3}{*}{$82 a$} & 0.075 & 5 & 31 \\
\hline & 0.150 & 3 & 26 \\
\hline & 0.225 & 2 & 21 \\
\hline \multirow{3}{*}{$82 b$} & 0.075 & 6 & 35 \\
\hline & 0.150 & 5 & 30 \\
\hline & 0.225 & 3 & 23 \\
\hline \multirow{3}{*}{$82 c$} & 0.075 & 6 & 34 \\
\hline & 0.150 & 4 & 28 \\
\hline & 0.225 & 2 & 23 \\
\hline \multirow{3}{*}{$82 d$} & 0.075 & 6 & 38 \\
\hline & 0.150 & 5 & 30 \\
\hline & 0.225 & 3 & 24 \\
\hline
\end{tabular}

Nitroheterocyclic molecules bearing the 1,3,4-oxadiazole group were reported as active against $T$. cruzi by Ishii et al..$^{70}$ Nitroheterocycles, such benznidazole and nifurtimox, are drugs known for their inhibitory activity against T. cruzi. However, they are also toxic to the mammalian host, being responsible for severe side effects such as anorexia, weight loss, nausea and vomit, nervous excitation, insomnia, psychic depression, convulsion, vertigo, headaches, sleepiness, balance disorder, memory loss and hepatic intoleration. ${ }^{71}$ The compounds 83a-o were planned based on the structure of nitroheterocyclic drugs. The antitrypanosomal activity was measured against epimastigote forms of $T$. cruzi (Y strain) along with reference drug benznidazole. $\mathrm{IC}_{50}$ values revealed all molecules are potent inhibitors. In fact, only compound $\mathbf{8 3} \mathbf{j}$ was less potent than benznidazole, but still comparable to the reference drug. The other derivatives in the series displayed $\mathrm{IC}_{50}$ values ranging from 1.4- to 2.6-fold lower than benznidazole. Derivative 830 was the most potent of the series showing an $\mathrm{IC}_{50}=7.91 \mu \mathrm{mol} \mathrm{L}-1$ against $T$. cruzi epimastigotes. The analysis of Table 12 shows a slightly higher activity for derivatives substituted with resonance electron-withdrawing groups $(\mathbf{8 3 m - 0}) .^{70}$

Taha et al..$^{72}$ discussed the antileishmanial potential of an extensive series of 30 1,3,4-oxadiazole-phenylhydrazones hybrids. In vitro antileishmanial activity was determined on THP-1 cells infected with Leishmania major. Cytotoxicity to mammalian cells was measured on THP-1 and U-937 cell lines. Pentamidine was used as the reference drug. All tested molecules displayed antileishmanial activity, with $\mathrm{IC}_{50}$ values ranging from $0.95 \pm 0.01 \mu \mathrm{mol} \mathrm{\textrm {L } ^ { - 1 }}$ to $78.6 \pm 1.78 \mu \mathrm{mol} \mathrm{L} \mathrm{L}^{-1}$. Thirteen of them exhibited $\mathrm{IC}_{50}$ values lower or comparable to pentamidine's $\left(\mathrm{IC}_{50}=7.02 \mu \mathrm{mol} \mathrm{L}{ }^{-1}\right)$. We selected for this review the seven most promising compounds (84a-g) based on their activity against $L$. major and calculated SI values. With the exception of $84 \mathrm{~g}$, all these compounds presented low toxicity against U-937 and THP-1 cells ( $\left.\mathrm{IC}_{50} \geq 100 \mu \mathrm{mol} \mathrm{L}^{-1}\right)$. Chemical structures of selected compounds with respective $\mathrm{IC}_{50}$ values are shown in Table 13. ${ }^{72}$ 
Table 12. Chemical structures and $\mathrm{IC}_{50}$ values against T. cruzi (epimastigotes, $\mathrm{Y}$ strain) of 1,3,4-oxadiazoles (83a-o)

\begin{tabular}{|c|c|c|c|c|c|c|c|c|}
\hline Compound & $\mathrm{R}$ & $\mathrm{IC}_{50} /\left(\mu \mathrm{mol} \mathrm{L}{ }^{-1}\right)$ & Compound & $\mathrm{R}$ & $\mathrm{IC}_{50} /\left(\mu \mathrm{mol} \mathrm{L} \mathrm{L}^{-1}\right)$ & Compound & $\mathrm{R}$ & $\mathrm{IC}_{50} /\left(\mu \mathrm{mol} \mathrm{L} \mathrm{L}^{-1}\right)$ \\
\hline $83 a$ & $-\mathrm{H}$ & 10.24 & $83 f$ & $-\mathrm{Me}$ & 11.47 & $83 k$ & $-\mathrm{O}^{\mathrm{n}} \mathrm{Pr}$ & 12.20 \\
\hline $83 b$ & $-\mathrm{Cl}$ & 10.85 & $83 g$ & $-\mathrm{Et}$ & 10.74 & 831 & $-\mathrm{O}^{\mathrm{n}} \mathrm{Bu}$ & 11.47 \\
\hline $83 c$ & $-\mathrm{Br}$ & 10.16 & $83 h$ & $-{ }^{\mathrm{n}} \mathrm{Pr}$ & 9.90 & $83 m$ & $-\mathrm{NO}_{2}$ & 9.85 \\
\hline $83 d$ & $-\mathrm{I}$ & 12.10 & $83 i$ & $-\mathrm{OMe}$ & 10.67 & $83 n$ & $-\mathrm{CN}$ & 8.19 \\
\hline \multirow[t]{2}{*}{$83 e$} & $-\mathrm{CF}_{3}$ & 14.25 & $83 \mathbf{j}$ & $-\mathrm{OEt}$ & 26.64 & 830 & $-\mathrm{CO}_{2} \mathrm{Me}$ & 7.91 \\
\hline & & & & & & benznidazole & - & 20.84 \\
\hline
\end{tabular}

Table 13. Chemical structures of 1,3,4-oxadiazoles (84a-g) with the respective $\mathrm{IC}_{50}$ values against L. major (JISH118), THP-1 and U-937 cell lines and SI values are shown

\begin{tabular}{|c|c|c|c|c|c|}
\hline Compound & $\mathrm{R}$ & $\mathrm{IC}_{50}$ L. major $/\left(\mu \mathrm{mol} \mathrm{L}^{-1}\right)$ & $\mathrm{SI}^{\mathrm{a}}$ & $\mathrm{IC}_{50}$ THP-1 $/(\mu \mathrm{mol} \mathrm{L}-1)$ & $\mathrm{IC}_{50} \mathrm{U}-937 /\left(\mu \mathrm{mol} \mathrm{L}^{-1}\right)$ \\
\hline $84 a$ & $2-\mathrm{F}$ & $5.18 \pm 0.08$ & 60.4 & $313.0 \pm 2.3$ & $\mathrm{NA}^{\mathrm{b}}$ \\
\hline $84 b$ & $3-\mathrm{F}$ & $6.35 \pm 0.02$ & 55.6 & $353.0 \pm 2.7$ & NA \\
\hline $84 c$ & $2-\mathrm{OH}$ & $4.14 \pm 0.06$ & 50.0 & $207.2 \pm 2.5$ & NA \\
\hline $84 d$ & $2,3-(\mathrm{OH})_{2}$ & $1.40 \pm 0.02$ & 72.6 & $101.6 \pm 1.4$ & NA \\
\hline $84 e$ & $3,4-(\mathrm{OH})_{2}$ & $0.95 \pm 0.01$ & 105.3 & $100.0 \pm 1.2$ & NA \\
\hline $84 f$ & $2,4-(\mathrm{OH})_{2}$ & $3.78 \pm 0.03$ & 27.5 & $103.9 \pm 1.2$ & NA \\
\hline $84 g$ & $2,4,5-(\mathrm{OH})_{3}$ & $0.98 \pm 0.01$ & 5.5 & $5.40 \pm 0.1$ & $7.46 \pm 0.1$ \\
\hline Pentamidine ${ }^{\mathrm{c}}$ & - & $7.02 \pm 0.09$ & 1.10 & $7.70 \pm 0.1$ & $6.02 \pm 0.10$ \\
\hline
\end{tabular}

${ }^{\mathrm{a}}$ Ratio between $\mathrm{IC}_{50}$ values against THP-1 and L. major; ${ }^{\mathrm{b}}$ not active; ${ }^{\mathrm{s}}$ standard drug.

Molecular docking studies were carried out on pteridine reductase (PTR1, PDB code: 1E7W). This enzyme, present in Leishmania species, is responsible for reduction of biopterin, a vital condition for in vitro parasite growth. ${ }^{73}$ Compounds $\mathbf{8 4 d}$-g were selected to investigate whether the mode of action of the 1,3,4-oxadiazoles described by Taha et al. ${ }^{72}$ could be related to PTR1 inhibition. The main interactions observed were hydrogen bonds between the differently oriented $-\mathrm{OH}$ groups and hydrogen bond acceptors on the binding site. In addition, well-formed $\pi-\pi$ stacking, cation- $\pi$, hydrophobic and hydrogen bond interactions are features that help the stabilization of test compounds on PTR $1 .^{72}$

Chaves et al. (2017) ${ }^{74}$ studied the antileishmanial activity of gold(I) complexes with 1,3,4-oxadiazole-2-thione derivatives. All of the complexes prepared for this work displayed $\mathrm{IC}_{50}$ values below $11 \mu \mathrm{mol} \mathrm{L} \mathrm{L}^{-1}$ for promastigotes (Leishmania infantum and Leishmania braziliensis) and $5 \mu \mathrm{mol} \mathrm{L} \mathrm{L}^{-1}$ for amastigotes (L. infantum). In addition, cytotoxicity to human macrophages THP-1 was determined for each compound, as well as the respective SI values. The biological assessment also included the evaluation of ligands and precursors involved on the synthesis of the complexes. Amphotericin B (AmB) was used as a positive control. Among this series, 85a-b were the most active candidates against intracellular amastigotes $\left(\mathrm{IC}_{50}=0.97\right.$ and $1.41 \mu \mathrm{mol} \mathrm{L}{ }^{-1}$, respectively). The chemical structures of complexes 85a-b and the respective oxadiazolic ligands 86a-b along with $\mathrm{IC}_{50}$ values for complexes, ligands, 
Table 14. Chemical structures of gold(I) complexes of 1,3,4-oxadiazole-2-thiones (85a-b) along with the respective ligands (86a-b) and in vitro antileishmanial and cytotoxicity results

\begin{tabular}{|c|c|c|c|c|c|c|}
\hline \multirow{2}{*}{ Compound } & \multirow{2}{*}{$\mathrm{R}$} & \multicolumn{2}{|c|}{$\mathrm{IC}_{50}$ promastigotes / $\left(\mu \mathrm{mol} \mathrm{L}{ }^{-1}\right)$} & \multirow{2}{*}{$\frac{\mathrm{IC}_{50} \text { amastigotes } /\left(\mu \mathrm{mol} \mathrm{L}{ }^{-1}\right)}{\text { L. infantum }}$} & \multirow{2}{*}{$\mathrm{IC}_{50}$ THP-1 $/(\mu \mathrm{mol} \mathrm{L}-1)$} & \multirow{2}{*}{$\mathrm{SI}^{\mathrm{a}}$} \\
\hline & & L. infantum & L. braziliensis & & & \\
\hline $85 a$ & $\mathrm{H}$ & 4.02 & 7.20 & 0.97 & 4.41 & 4.54 \\
\hline 85b & $\mathrm{NO}_{2}$ & 5.38 & 9.27 & 1.41 & 6.37 & 4.51 \\
\hline $86 a$ & $\mathrm{H}$ & $>100$ & $>100$ & - & $>50$ & - \\
\hline 86b & $\mathrm{NO}_{2}$ & 27.56 & 32.40 & - & $>50$ & - \\
\hline $\mathrm{Au}\left(\mathrm{PEt}_{3}\right) \mathrm{Cl}$ & - & 1.94 & 2.79 & 1.35 & 5.43 & 3.77 \\
\hline $\mathrm{AmB}^{\mathrm{b}}$ & - & 0.10 & 0.10 & 0.09 & 12.00 & 133 \\
\hline
\end{tabular}

a Ratio between $\mathrm{IC}_{50}$ values against THP-1 and amastigotes of $L$. infantum; ${ }^{\mathrm{b}}$ standard drug.

the precursor $\mathrm{Au}\left(\mathrm{PEt}_{3}\right) \mathrm{Cl}$ and $\mathrm{AmB}$ are displayed on Table $14 .^{74}$

In addition, authors concluded that novel gold(I) complexes can be useful for understanding and overcoming drug resistance in Leishmania. $\mathrm{Sb}^{\mathrm{v}}$-based drugs such as pentostam and glucantime are prodrugs. They are reduced in biological media assuming their $\mathrm{Sb}^{\mathrm{III}}$ active form. These drugs act mostly through inhibition of trypanothione reductase (TryR), disrupting the parasite's redox homeostasis. Gold(I) complexes can act through similar pathways with no cross resistance for Sb-resistant Leishmania parasites. Several biochemical and biophysical changes were observed in parasite's cells, including increased membrane fluidity. However, the mechanism of action related to gold(I) effects on Sb-resistant Leishmania parasites needs to be further investigated. ${ }^{74}$

\section{Concluding Remarks and Perspectives}

Regarding their occurrence in the structure of biologically active molecules, 1,2,4- and 1,3,4-oxadiazoles notably stand out from their two other isomers. These heterocycles can mimic amide and esters in the biological environment, behaving as bioisosters of these functions, with the advantage of being resistant to hydrolysis reactions. The structural and electronic differences regarding the aromaticity of 1,2,4- and 1,3,4-oxadiazoles have an important influence on the possible interactions that these nuclei carry out with several bioreceptors. Their relevance is also due to the several synthetic alternatives for their preparation, in addition to the possibility of these heterocycles presenting different substitution patterns, pointing them as scaffolds on which new chemical entities possessing high structural diversity can be planned and easily prepared. Then, 1,2,4- and 1,3,4-oxadiazoles emerge as structural subunits of great importance and versatility for the development of new drug candidates applicable to the treatment of parasitic infections, especially in the field of NTDs. Certainly, in the coming years, we will see an increasing number of works using oxadiazolic nuclei as scaffolds in the design and synthesis of new antiparasitic drug candidates, in addition to other therapeutic applications.

\section{Acknowledgments}

The authors are grateful to the research promotion agencies FAPERJ, CNPq and CAPES for the financial supports given.

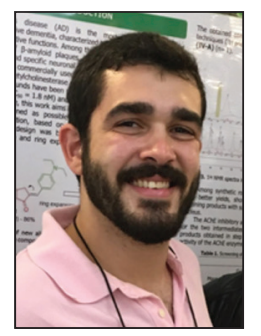

Paulo Pitasse-Santos received a $B S$ degree in Chemical Engineering from the Federal Rural University of Rio de Janeiro (2014); a Master's degree in Chemistry from the same University (2017). Nowadays, he is a PhD student (PPGQ-UFRRJ) working on the design and synthesis of new peptide-drug conjugates, under the supervision of Prof Marco E. F. Lima.

Vitor Sueth-Santiago got a BS degree in Pharmacy from the School of Pharmacy of the Federal University of Rio de Janeiro (2009); a Master's degree in Chemistry from the 


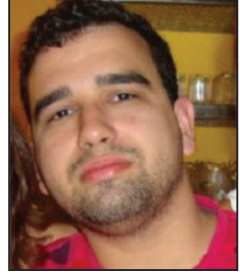

same University (2011); and a PhD in Chemistry from the Federal Rural University of Rio de Janeiro (2015) working under the supervision of Prof Marco E. F. Lima. He is currently Professor of Organic Chemistry at the Federal Institute of Education, Science and Technology of Rio de Janeiro. He has experience in the field of medicinal chemistry and organic synthesis.

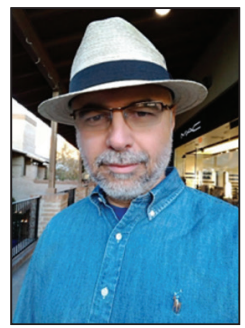

Marco Edilson Freire de Lima is a full professor in the Department of Chemistry of the Institute of Exact Sciences at the Federal Rural University of Rio de Janeiro (Seropédica, RJ, Brazil). He worked as a visiting researcher at Prof Victor Hruby's group (2015-2016) at the University of Arizona (Tucson, AZ, USA) on the design and synthesis of peptides for medicinal purposes. Prof Lima received his PhD in Sciences (1994) from IQ-UFRJ working under the supervision of Prof Andrew E. Greene at LEDSS-3 (University of Grenoble-France, 1991-1993) in the total synthesis of natural products using the [2+2] cycloaddition reaction of dichloroketene to olefins. He got a Master's in Sciences degree (1989) from IQ-UFRJ working on the design and synthesis of new anti-inflammatory drugs under the supervision of Prof Eliezer J. Barreiro; and he got a BS degree in Pharmacy from the School of Pharmacy of the Federal University of Rio de Janeiro (1986). Prof Lima's research interests include the design and synthesis of new chemical entities potentially useful as antiparasitic drugs with a major emphasis on neglected infectious diseases. He has been the director of the Medicinal \& Biological Chemistry section of the Brazilian Chemical Society (2010-2012).

\section{References}

1. Li, J. J.; Heterocyclic Chemistry in Drug Discovery, $1^{\text {st }}$ ed.; Wiley: New York, USA, 2013.

2. Vitaku, E.; Smith, D. T.; Njardarson, J. T.; J. Med. Chem. 2014, $57,10257$.

3. Baumann, M.; Baxandele, I. R.; Ley, S. V.; Nikbin, N.; Beilstein J. Org. Chem. 2011, 7, 442; Baumann, M.; Baxandele, I.; Beilstein J. Org. Chem. 2013, 9, 2265.

4. Ghannoum, M. A.; Rice, L. B.; Clin. Microbiol. Rev. 1999, 12, 501.

5. Edwards, D. I.; J. Antimicrob. Chemother. 1993, 31, 201; Trochine, A.; Creek, D. J.; Faral-Tello, P.; Barrett, M. P.; Robello, C.; PLoS Neglected Trop. Dis. 2014, 8, e2844.
6. Pommier, Y.; Leo, E.; Zhang, H.; Marchand, C.; Chem. Biol. 2010, 17, 421.

7. Muscadet, J. F.; Tchertanov, L.; Eur. J. Med. Res. 2009, 14, 5.

8. Tiemann, F.; Kruger, P.; Ber. Dtsch. Chem. Ges. 1884, 17, 1685.

9. Gupta, R. R.; Kumar, M.; Gupta, V.; Heterocyclic Chemistry: Five Membered Heterocycles, $1^{\text {st }}$ ed.; Springer: India, 2005.

10. Clapp, L. B.; Adv. Heterocycl. Chem. 1976, 20, 65.

11. Ongungal, R. M.; Sivadas, A. P.; Kumar, N. S.; Menon, S.; Das, S.; J. Mater. Chem. C 2016, 4, 9588; Mitani, M.; Yoshio, M.; Kato, T.; J. Mater. Chem. C 2017, 5, 9972; Bruno, A.; Borriello, C.; Di Luccio, T.; Sessa, L.; Concilio, S.; Haque, S. A.; Minarini, C.; Opt. Mater. 2017, 66, 166.

12. Shih, C. H.; Rajamalli, P.; Wu, C. A.; Chiu, M. J.; Chu, L. K.; Cheng, C. H.; J. Mater. Chem. C 2015, 3, 1491; Zhao, Z.; Yin, Z.; Chen, H.; Guo, Y.; Tang, Q.; Liu, Y.; J. Mater. Chem. C 2017, $5,9972$.

13. Ko, D.; Patel, H. A.; Yavuz, C. T.; Chem. Commun. 2015, 51, 2915; Anghel, C.; Matache, M.; Paraschivescu, C. C.; Madalan, A. M.; Andruh, M.; Inorg. Chem. Commun. 2017, 76, 22.

14. Kraus, H.; Witschel, M.; Seitz, T.; Newton, T. W.; Rapado, L. P.; Aponte, R.; Kreuz, K.; Grossmann, K.; Lerchl, J.; Evans, R. R.; US pat. 9,096,583 2015 (CA 2853340 A1); Zhang, D.; Hua, X.; Liu, M.; Wu, C.; Wei, W.; Liu, Y.; Chen, M.; Zhou, S.; Li, Y.; Li, Z.; Chem. Res. Chin. Univ. 2016, 32, 607.

15. Bouanis, M.; Tourabi, M.; Nyassi, A.; Zarrouk, A.; Jama, C.; Bentiss, F.; Appl. Surf. Sci. 2016, 389, 952; Shirazi, Z.; Keshavarz, M. H.; Esmaeilpour, K.; Golikand, A. N.; Prot. Met. Phys. Chem. Surf. 2017, 53, 359.

16. Nobeli, I.; Price, S. L.; Lommerse, J. P. M.; Taylor, R.; J. Comput. Chem. 1997, 18, 2060.

17. Lima, L. M.; Barreiro, E. J.; Curr. Med. Chem. 2005, 12, 23.

18. Bostrom, J.; Hogner, A.; Schmitt, S.; J. Med. Chem. 2006, 49, 6716.

19. Carbone, M.; Li, Y.; Irace, C.; Mollo, E.; Castelluccio, F.; Di Pascale, A.; Cimino, G.; Santamaria, R.; Guo, Y. W.; Gavagnin, M.; Org. Lett. 2011, 13, 2516.

20. Alder, J.; Hancock, A.; Trans. Zool. Soc. London 1864, 5, 113.

21. Brogan, J. T.; Stoops, S. L.; Lindsley, C. W.; ACS Chem. Neurosci. 2012, 3, 658.

22. Web of Science database, available at https://webofknowledge. com. Keywords: 1,2,3-oxadiazole, 1,2,4-oxadiazole, 1,3,4-oxadiazole, 1,2,5-oxadiazole; Filters: Chemistry Medicinal or Pharmacology Pharmacy, accessed in October 2017.

23. Porta, F.; Facchetti, G.; Ferri, N.; Gelain, A.; Meneghetti, F.; Villa, S.; Barlocco, D.; Masciocchi, D.; Asai, A.; Miyoshi, N.; Marchianò, S.; Eur. J. Med. Chem. 2017, 131, 196; Ragab, F. A.; Abou-Seri, S. M.; Abdel-Aziz, S. A.; Alfayomy, A. M.; Aboelmagd, M.; Eur. J. Med. Chem. 2017, 138, 140.

24. Mihailović, N.; Marković, V.; Matić, I. Z.; Stanisavljević, N. S.; Jovanović, Ž. S.; Trifunović, S.; Joksović, L.; RSC Adv. 2017, 7, 8550; Sauer, A. C.; Leal, J. G.; Stefanello, S. T.; Leite, M. 
T.; Souza, M. B.; Soares, F. A.; Rodrigues, O. E.; Dornelles, L.; Tetrahedron Lett. 2017, 58, 87.

25. Wang, P. Y.; Zhou, L.; Zhou, J.; Fang, H. S.; Wu, Z. B.; Xue, W.; Song, B. A.; Yang, S.; Chem. Pap. 2017, 71, 1013; Zhang, T. T.; Wang, P. Y.; Zhou, J.; Shao, W. B.; Fang, H. S.; Zhou, X.; Wu, Z. B.; J. Heterocycl. Chem. 2017, 54, 2319.

26. Gan, X.; Hu, D.; Chen, Z.; Wang, Y.; Song, B.; Bioorg. Med. Chem. Lett. 2017, 27, 4298; Benmansour, F.; Trist, I.; Coutard, B.; Decroly, E.; Querat, G.; Brancale, A.; Barral, K.; Eur. J. Med. Chem. 2017, 125, 865.

27. Rathore, A.; Sudhakar, R.; Ahsan, M. J.; Ali, A.; Subbarao, N.; Jadav, S. S.; Umar, S.; Yar, M. S.; Bioorg. Chem. 2017, 70, 107; Abd-Ellah, H. S.; Abdel-Aziz, M.; Shoman, M. E.; Beshr, E. A.; Kaoud, T.; Ahmed, A. S. F.; Bioorg. Chem. 2017, 74, 15.

28. Liu, Q.; Zhu, R.; Gao, S.; Ma, S. H.; Tang, H. J.; Yang, J. J.; Diao, Y. M.; Wang, H. L.; Zhu, H. J.; Pest Manage. Sci. 2017, 73, 917; Tok, F.; Kocyigit-Kaymakcioglu, B.; Tabanca, N.; Estep, A. S.; Gross, A. D.; Geldenhuys, W. J.; Becnel, J. J.; Bloomquist, J. R.; Pest Manage. Sci. 2017, in press. DOI: 10.1002/ps.4722.

29. Patel, N. B.; Patel, J. N.; Purohit, A. C.; Patel, V. M.; Rajani, D. P.; Moo-Puc, R.; Lopez-Cedillo, J. C.; Nogueda-Torres, B.; Rivera, G.; Int. J. Antimicrob. Agents 2017, 50, 413; Thakkar, S. S.; Thakor, P.; Doshi, H.; Ray, A.; Bioorg. Med. Chem. 2017, 25, 4064.

30. Semenov, S. G.; Sigolaev, Y. F.; J. Struct. Chem. 2004, 45, 1082; Sugihara, T.; Kuwahara, K.; Wakabayashi, A.; Takao, H.; Imagawa, H.; Nishizawa, M.; Chem. Commun. 2004, 2, 216.

31. Song, L. J.; Luo, H.; Fan, W. H.; Wang, G. P.; Yin, X. R.; Shen, S.; Wang, J.; Jin, Y.; Zhang, W.; Gao, H.; Liu, Q.; Parasites Vectors 2016, 9, 26; Melo-Filho, C. C.; Dantas, R. F.; Braga, R. C.; Neves, B. J.; Senger, M. R.; Valente, W. C.; Rezende-Neto, J. M.; Chaves, W. T.; Muratov, E. N.; Paveley, R. A.; Furnham, N.; J. Chem. Inf. Model. 2016, 56, 1357.

32. de Souza, A. S.; de Oliveira, M. T.; Andricopulo, A. D.; J. Comput.-Aided Mol. Des. 2017, 31, 801.

33. Moussebois, C.; Oth, J. F. M.; Helv. Chim. Acta 1964, 47, 942.

34. Trifonov, R. E.; Ostrovskii, V. A.; Chem. Heterocycl. Compd. 2006, $42,657$.

35. Li, A. F.; Ruan, Y. B.; Jiang, Q. Q.; He, W. B.; Jiang, Y. B.; Chem. - Eur. J. 2010, 16, 5794.

36. Srivastava, R. M.; Rosa, M. F.; Carvalho, C. E. M.; Heterocycles 2000, 53, 191.

37. Dhumal, S. T.; Deshmukh, A. R.; Bhosle, M. R.; Khedkar, V. M.; Nawale, L. U.; Sarkar, D.; Mane, R. A.; Bioorg. Med. Chem. Lett. 2016, 26, 3646.

38. Ma, J. C.; Dougherty, D. A.; Chem. Rev. 1997, 97, 1303.

39. Taha, M.; Ismail, N. H.; Imran, S.; Wadood, A.; Rahim, F.; Saad, S. M.; Khan, K. M.; Nasir, A.; Bioorg. Chem. 2016, 66, 117.

40. Wei, C.; Liu, Z.; Zhang, D.; Mei, Y.; J. Theor. Comput. Chem. 2010, 9, 1053.
41. Mohammadi-Khanaposhtani, M.; Shabani, M.; Faizi, M.; Aghaei, I.; Jahani, R.; Sharafi, Z.; Zafarghnandi, N. S.; Mahdavi, M.; Akbarzedeh, T.; Emami, S.; Shafiee, A.; Foroumadi, A.; Eur. J. Med. Chem. 2016, 112, 91.

42. Kamal, A.; Reddy, T. S.; Vishnuvardhan, M. V. P. S.; Nimbarte, V. D.; Rao, A. S.; Srinivasulu, V.; Shankaraiah, N.; Bioorg. Med. Chem. 2015, 23, 4608.

43. Outirite, M.; Lagrenée, M.; Hammouti, B.; Bentiss, F.; Res. Chem. Intermed. 2015, 41, 1601.

44. Bretanha, L. C.; Teixeira, V. E.; Ritter, M.; Siqueira, G. M.; Cunico, W.; Pereira, C. M.; Freitag, R. A.; Ultrason. Sonochem. 2011, 18, 704.

45. Yoshimura, A.; Nguyen, K. C.; Klasen, S. C.; Postnikov, P. S.; Yusubov, M. S.; Saito, A.; Nemykin, V. N.; Zhdankin, V. V.; Asian J. Org. Chem. 2016, 5, 1128.

46. Karad, S. C.; Purohit, V. B.; Thummar, R. P.; Vaghasiya, B. K.; Kamani, R. D.; Thakor, P.; Thakkar, V. R.; Thakkar, S. S.; Ray, A.; Raval, D. K.; Eur. J. Med. Chem. 2017, 126, 894.

47. Cao, Y.; Min, C.; Acharya, S.; Kim, K. M.; Cheon, S. H.; Bioorg. Med. Chem. 2016, 24, 191.

48. Zhao, J. J.; Wang, X. F.; Li, B. L.; Zhang, R. L.; Li, B.; Liu, Y. M.; Li, C. W.; Liu, J. B.; Chen, B. Q.; Bioorg. Med. Chem. Lett. 2016, 26, 4414.

49. Desai, N. C.; Somani, H.; Trivedi, A.; Bhatt, K.; Nawale, L.; Khedkar, V. M.; Jha, P. C.; Sarkar, D.; Bioorg. Med. Chem. Lett. 2016, 26, 1776.

50. Niu, P.; Kang, J.; Tian, X.; Song, L.; Liu, H.; Wu, J.; Yu, W.; Chang, J.; J. Org. Chem. 2014, 80, 1018.

51. Sangshetti, J. N.; Dharmadhikari, P. P.; Chouthe, R. S.; Fatema, B.; Lad, V.; Karande, V.; Darandale, S. N.; Shinde, D. B.; Bioorg. Med. Chem. Lett. 2013, 23, 2250.

52. Suresh, D.; Kanagaraj, K.; Pitchumani, K.; Tetrahedron Lett. 2014, 55, 3678.

53. Rouhani, M.; Ramazani, A.; Joo, S. W.; Ultrason. Sonochem. 2015, 22, 391.

54. Daumerie, D.; Savioli, L.; Crompton, D. W. T.; Peters, P.; Working to Overcome the Global Impact of Neglected Tropical Diseases: First WHO Report on Neglected Tropical Diseases, $1^{\text {st }}$ ed.; World Health Organization: Geneva, Switzerland, 2010.

55. Vaidya, A.; Jain, S.; Jain, P.; Jain, P.; Tiwari, N.; Jain, R.; Jain, R.; Jain, A. K.; Agrawal, R. K.; Mini.-Rev. Med. Chem. 2016, 16, 825; Shukla, C.; Srivastava, S.; J. Drug Delivery Ther. 2015, 5, 8; Bora, R. O.; Dar, B.; Pradhan, V.; Farooqui, M.; Mini-Rev. Med. Chem. 2014, 14, 355; Patel, K. D.; Prajapati, S. M.; Panchal, S. N.; Patel, H. D.; Synth. Commun. 2014, 44, 1859; de Oliveira, C. S.; Lira, B. F.; Barbosa-Filho, J. M.; Lorenzo, J. G. F.; de Athayde-Filho, P. F.; Molecules 2012, 17, 10192; Kumar, K. A.; Jayaroopa, P.; Kumar, G. V.; Int. J. ChemTech Res. 2012, 4, 1782; Pace, A.; Pierro, P.; Org. Biomol. Chem. 2009, 7, 4337.

56. Ainsworth, C.; Buting, W. E.; Davenport, J.; Callender, M. E.; McCowen, M. C.; J. Med. Chem. 1967, 10, 208. 
57. Haugwitz, R. D.; Martinez, A. J.; Venslavsky, J.; Angel, R. G.; Maurer, B. V.; Jacobs, G. A.; Szanto, J.; J. Med. Chem. 1985, 28, 1234.

58. Havens, C. G.; Bryant, N.; Asher, L.; Lamoreaux, L.; Perfetto, S.; Brendle, J. J.; Werbovetz, K. A.; Mol. Biochem. Parasitol. 2000, 110, 223.

59. Cottrell, D. M.; Capers, J.; Salem, M. M.; DeLuca-Fradley, K.; Croft, S. L.; Werbovetz, K. A.; Bioorg. Med. Chem. 2004, 12, 2815.

60. Santos-Filho, J. M.; Leite, A. C. L.; Oliveira, B. G.; Moreira, D. R. M.; Lima, M. S.; Soares, M. B. P.; Leite, L. F. C. C.; Bioorg. Med. Chem. 2009, 17, 6682.

61. Sajid, M.; McKerrow, J. H.; Mol. Biochem. Parasitol. 2002, $120,1$.

62. Dürüst, Y.; Karaku , H.; Kaiser, M.; Tasdemir, D.; Eur. J. Med. Chem. 2012, 48, 296.

63. Santos-Filho, J. M.; Macedo, T. S.; Teixeira, H. M. P.; Moreira, D. R. M.; Challal, S.; Wolfender, J. L.; Queiroz, E. F.; Soares, M. B. P.; Bioorg. Med. Chem. 2016, 24, 5693.

64. Hutt, M. P.; Elslager, E. F.; Werbel, L. M.; J. Heterocycl. Chem. 1970, 7, 511.

65. Martin-Smith, M.; Sneader, W. E.; Schier, O.; Marxer, A.; Mellett, L. B.; Elslager, E. F.; Bencze, W. L.; Hess, R.; DeStevens, G.; Mashkovsky, M. D.; Yakhontov, L. N.; Ankier, S. I. In Progress in Drug Research/Fortschritte der Arzneimittelforschung/ Progrès des Recherches Pharmaceutiques; Elslager, E. F.; Jucker, E., eds.; Birkhäuser Basel: Basel, Switzerland, 1969 , ch. 4 .
66. Balaji, K.; Bhatt, P.; Jha, A.; Drug Res. 2016, 66, 587.

67. Das, B. P.; Wallace, R. A.; Boykin Jr., D. W.; J. Med. Chem. 1980, 23, 578.

68. Das, B. P.; Boykin, D. W.; J. Med. Chem. 1977, 20, 531.

69. Patel, K.; Chandran, J. E.; Shah, R.; Vijaya, J.; Sreenivasa, G. M.; Int. J. Pharma Bio Sci. 2010, $1,1$.

70. Ishii, M.; Jorge, S. D.; de Oliveira, A. A.; Palace-Berl, F.; Sonehara, I. Y.; Pasqualoto, K. F. M.; Tavares, L. C.; Bioorg. Med. Chem. 2011, 19, 6292.

71. Castro, J. A.; Diaz, D. T. E.; Biomed. Environ. Sci. 1988, 1, 19; Maya, J. D.; Cassels, B. K.; Iturriaga-Vásquez, P.; Ferreira, J.; Faundez, M.; Galanti, N.; Ferreira, A.; Morello, A.; Comp. Biochem. Physiol., Part A: Mol. Integr. Physiol. 2007, 146, 601.

72. Taha, M.; Ismail, N. H.; Imran, S.; Selvaraj, M.; Jamil, W.; Ali, M.; Kashiff, S. M.; Rahim, F.; Khan, K. M.; Adenan, M. I.; Eur. J. Med. Chem. 2017, 126, 1021.

73. Nare, B.; Luba, J.; Hardy, L. W.; Beverly, S.; Parasitology 1997, 114, S101; Sienkiewicz, N.; Ong, H. B.; Fairlamb, A. H.; Mol. Microbiol. 2010, 77, 658.

74. Chaves, J. D. S.; Tunes, L. G.; Franco, C. H. D. J.; Francisco, T. M.; Corrêa, C. C.; Murta, S. M.; Monte-Neto, R. L.; Silva, H.; Fontes, A. P. S.; Almeida, M. V.; Eur. J. Med. Chem. 2017, 127,727 . 